\title{
Paleoceanography
}

\section{RESEARCH ARTICLE \\ 10.1002/2016PA003007 \\ Latest Cretaceous climatic and environmental change in the South Atlantic region}

Key Points:

- South Atlantic late Maastrichtian temperature records show an $\sim 2.5-4^{\circ} \mathrm{C}$ warming coinciding with a Deccan outpouring phase

- Biotic changes suggest an expanding and strengthening thermal low over the South American continent during this warming

Supporting Information:

- Supporting Information S1

- Table S1

- Table S3

- Table S4

- Data Set S1

- Data Set S2

Correspondence to:

L. Woelders,

lineke.woelders@gmail.com

\section{Citation:}

Woelders, L., et al. (2017), Latest Cretaceous climatic and environmental change in the South Atlantic region, Paleoceanography, 32, 466-483, doi:10.1002/2016PA003007.

Received 20 JUL 2016 Accepted 22 MAR 2017 Accepted article online 30 MAR 2017 Published online 4 MAY 2017

\author{
L. Woelders ${ }^{1}$ (D) J. Vellekoop ${ }^{1}$, D. Kroon ${ }^{2}$, J. Smit ${ }^{3}$ (D) S. Casadío ${ }^{4}$, M. B. Prámparo ${ }^{5}$ (D), \\ J. Dinarès-Turell ${ }^{6}$, F. Peterse ${ }^{7}$, A. Sluijs ${ }^{7}$, J. T. M. Lenaerts ${ }^{8}$ iD, and R. P. Speijer ${ }^{1}$ (iD)
}

${ }^{1}$ Department of Earth and Environmental Sciences, KU Leuven, Leuven, Belgium, ${ }^{2}$ School of GeoSciences, Grant Institute, University of Edinburgh, Edinburgh, UK, ${ }^{3}$ Event Stratigraphy, VU University Amsterdam, Amsterdam, Netherlands, ${ }^{4}$ CONICET, Universidad Nacional de Rio Negro, General Roca, Argentina, ${ }^{5}$ IANIGLA CCT-CONICET, Mendoza, Argentina, ${ }^{6}$ Istituto Nazionale di Geofisica e Vulcanologia, Rome, Italy, ${ }^{7}$ Department of Earth Sciences, Faculty of Geosciences, Utrecht University, Utrecht, Netherlands, ${ }^{8}$ Institute for Marine and Atmospheric Research, Utrecht University, Utrecht, Netherlands

Abstract Latest Maastrichtian climate change caused by Deccan volcanism has been invoked as a cause of mass extinction at the Cretaceous-Paleogene (K-Pg) boundary ( 66.0 Ma). Yet late Maastrichtian climate and ecological changes are poorly documented, in particular on the Southern Hemisphere. Here we present upper Maastrichtian-lower Danian climate and biotic records from the Bajada del Jagüel (BJ) shelf site (Neuquén Basin, Argentina), employing the $\mathrm{TEX}_{86}$ paleothermometer, marine palynology (dinoflagellate cysts), and micropaleontology (foraminifera). These records are correlated to the astronomically tuned Ocean Drilling Program Site 1262 (Walvis Ridge). Collectively, we use these records to assess climatic and ecological effects of Deccan volcanism in the Southern Atlantic region. Both the TEX ${ }_{86}$-based sea surface temperature (SST) record at BJ and the bulk carbonate $\delta^{18} \mathrm{O}$-based SST record of Site 1262 show a latest Maastrichtian warming of $\sim 2.5-4^{\circ} \mathrm{C}$, at 450 to $150 \mathrm{kyr}$ before the K-Pg boundary, coinciding with the a large Deccan outpouring phase. Benthic foraminiferal and dinocyst assemblage changes indicate that this warming resulted in enhanced runoff and stratification of the water column, likely resulting from more humid climate conditions in the Neuquén Basin. These climate conditions could have been caused by an expanding and strengthening thermal low over the South American continent. Biotic changes in response to late Maastrichtian environmental changes are rather limited, when compared to the major turnovers observed at many K-Pg boundary sites worldwide. This suggests that environmental perturbations during the latest Maastrichtian warming event were less severe than those following the K-Pg boundary impact.

\section{Introduction}

It is generally assumed that the Chicxulub asteroid impact ( $\sim 66.0 \mathrm{Ma})$ was the main cause of the CretaceousPaleogene (K-Pg) boundary mass extinction [e.g., Alvarez et al., 1980; Schulte et al., 2010], one of the "Big Five" mass extinctions during the Phanerozoic. The proposed triggers for the mass extinction following the impact include an impact winter [Vellekoop et al., 2014; Brugger et al., 2016], followed by global warming [Vellekoop et al., 2014, 2016] and ocean acidification [Kring, 2007]. However, the contribution of latest Maastrichtian Deccan Traps volcanism and climate disruption [Archibald et al., 2010; Schoene et al., 2015] to the mass extinction continues to be under debate.

A phase of $2-8^{\circ} \mathrm{C}$ latest Maastrichtian warming between $\sim 40$ and $\sim 100 \mathrm{kyr}$ before the K-Pg boundary has been recognized in many records, both marine [Barrera and Savin, 1999, and references therein; Olsson et al., 2002; Tobin et al., 2012; Petersen et al., 2016; Vellekoop et al., 2016] as well as terrestrial [Nordt et al., 2003; Wilf et al., 2003; Kemp et al., 2014] suggesting that this is a global signal. It has been postulated that this warming interval coincided with one of the largest Deccan outpouring phases [Ravizza and PeuckerEhrenbrink, 2003; Schoene et al., 2015]. These climate changes and environmental perturbations prior to the Chicxulub impact [e.g., Schmidt et al., 2016] are proposed to have resulted in global ecosystem instability. However, it remains unresolved if and how Deccan Trap volcanism would have led to extinction [Ravizza and Peucker-Ehrenbrink, 2003; Richards et al., 2015; Punekar et al., 2016].

Regarding open ocean plankton, little evidence exists for loss of species or population abundance during Late Cretaceous Deccan volcanism [Henehan et al., 2016]. Nevertheless, several late Maastrichtian ecological signals, such as anomalous abundances, migrations and dwarfism amongst planktic foraminifera [Olsson 


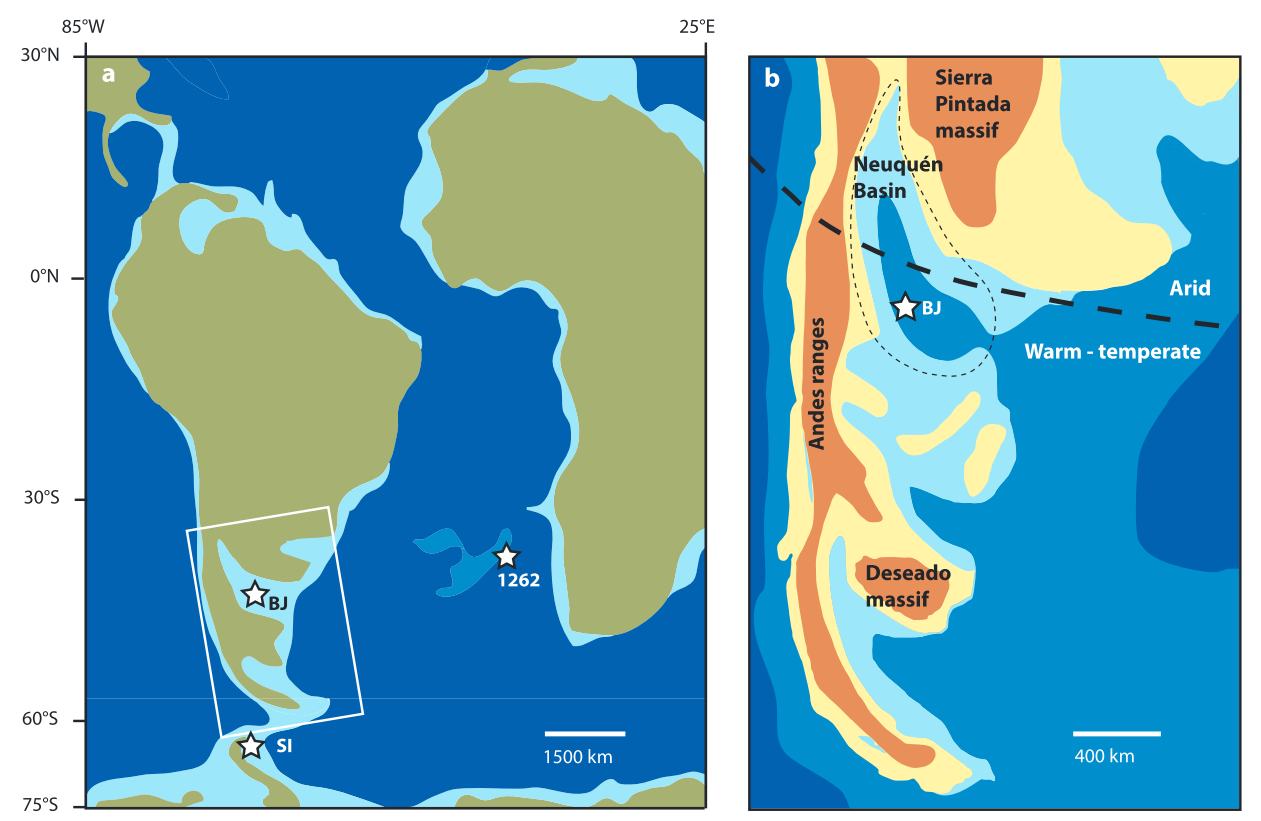

Figure 1. (a) Paleogeographic map of the South Atlantic during the latest Maastrichtian, modified after Scotese and Dreher [2012], showing the location of Bajada del Jagüel $\left(\mathrm{BJ} ; \sim 43^{\circ} \mathrm{S}\right)$, ODP Site $1262\left(\sim 40^{\circ} \mathrm{S}\right)$, and Seymour Island $\left(\mathrm{Sl} ; 65^{\circ} \mathrm{S}\right)$. Paleolatitudes are based on the magnetic reference frame of Torsvik et al. [2012] and calculated using paleolatitude.org [van Hinsbergen et al., 2015]. (b) Paleogeographic map modified after Scasso et al. [2012] with BJ in the Neuquén Basin, Argentina (marked by a gray dashed line). Dark blue: deep-sea basin. Light blue: shallow sea. Yellow: low land. Brown: higher land. Climate belts according to Boucot et al. [2013].

et al., 2001; Abramovich et al., 2010; Keller et al., 2016] and calcareous nannoplankton species [Thibault and Gardin, 2010; Thibault and Husson, 2016, and references therein] and the global bloom of the dinoflagellate Manumiella seelandica [Habib and Saeedi, 2007] hint toward biotic response to late Maastrichtian climate changes.

To understand the contribution of late Maastrichtian climate and environmental changes to the K-Pg boundary mass extinction, well-dated paleoclimate records with sufficient temporal resolution are required. Unfortunately, many available late Maastrichtian $\delta^{18} \mathrm{O}$ and other temperature records are of a relatively low resolution of 100 ka [Barrera and Savin, 1999; Tobin et al., 2012; Petersen et al., 2016]. Furthermore, some records yield hiatuses in the upper Maastrichtian interval [Barrera and Savin, 1999] or low signal-to-noise ratios [e.g., Li and Keller, 1998; Barrera and Savin, 1999; Wilf et al., 2003; Petersen et al., 2016]. This makes accurately pinpointing the onset and duration of the latest Maastrichtian warming interval problematic and complicates the quantification of the magnitude of the warming. In addition, apart from several Antarctic studies [e.g., Tobin et al., 2012; Petersen et al., 2016; Witts et al., 2016], ecological studies have thus far focused mostly on Northern Hemisphere locations and/or on deep-sea settings. Finally, existing literature disagrees on preimpact ecological changes in Southern Hemisphere high-latitude areas [e.g., Tobin et al., 2012; Witts et al., 2016]. Together, this hampers our understanding of the nature and extent of global climate and other environmental changes prior to the Chicxulub impact. Here we perform an organic geochemical, benthic foraminiferal, and palynological study on a Southern Hemisphere midlatitude site to increase our understanding of late Maastrichtian climate and resulting environmental changes.

The upper Maastrichtian midlatitude sedimentary record of the Bajada del Jagüel (BJ) site, in the Neuquén Basin in Argentina (Figure 1), is well suited to study climate and environmental changes in a marginal marine setting in the Southern Hemisphere. Such marginal marine records generally experience high sedimentation rates, potentially providing high-resolution records and information on land-ocean interactions. Crucially, during the Maastrichtian, the Neuquén Basin was located near the transition between two climate zones, with a semiarid climate belt situated north of the basin and a humid, warm-temperate climate belt south of the basin [Chumakov et al., 1995; Boucot et al., 2013] (Figure 1), increasing its sensitivity to record environmental changes. 
The absence of open marine, keeled planktic foraminifera, including most stratigraphic marker taxa [Keller et al., 2007] and of a magnetostratigraphic record hamper an accurate age assessment of latest Maastrichtian environmental and biotic changes at the study site. Fortunately, organic-walled dinoflagellate cysts (dinocysts) are abundant in the uppermost Maastrichtian deposits of the Neuquén Basin [Papú et al., 1996; Prámparo and Papú, 2006] and can provide an alternative powerful biostratigraphic tool [Brinkhuis and Zachariasse, 1988; Schiøler et al., 1997; Prámparo and Papú, 2006; Açıkalın et al., 2015; Vellekoop et al., 2015, 2016].

Recrystallization of shell carbonate inhibits the use of traditional carbonate-based sea surface temperature (SST) proxies at BJ. Therefore, we employ the lipid biomarker-based paleothermometer TEX ${ }_{86}$ [Schouten et al., 2002] following recent successful applications in K-Pg shelf studies [Vellekoop et al., 2014, 2016]. Organic biomarkers are expected to be well preserved, since the soft, clay-rich upper Maastrichtian-lower Danian sediments of BJ have not been buried deeply [Arregui et al., 2011] and have most likely not experienced heating caused by volcanic activity [Folguera et al., 2011]. Organic biomarkers can also be used to assess the relative input of soil organic carbon using the Branched and Isoprenoid Tetraether (BIT) index [Hopmans et al., 2004], which is often considered as a proxy for terrestrial input in marine records [e.g., Ménot et al., 2006]. Furthermore, we use palynology, notably dinocysts, to provide insight in nutrient availability, salinity, and coastal proximity [e.g., Sluijs et al., 2005; Vellekoop et al., 2015], and benthic foraminifera to reveal sea level changes, in addition to changes in oxygenation and food supply in this neritic environment [e.g., Corliss and Chen, 1988; Jorissen et al., 2007; Woelders and Speijer, 2015]. Importantly, since benthic foraminifera and especially organic-walled cyst-producing dinoflagellates experienced relatively few extinctions across the K-Pg boundary [Brinkhuis and Zachariasse, 1988; Culver, 2003; Woelders and Speijer, 2015], these biota are ideally suited to assess the environmental and ecological change before and after the K-Pg boundary. To be able to investigate the relationship between these changes and Deccan Traps volcanism and climatic disruption, knowledge on the exact timing of these changes is required. While the biostratigraphic age model of the $\mathrm{BJ}$ section is sufficient to assess the relative timing of environmental changes at this locality, no astronomically tuned age model exists for this site. Yet the deep-sea record from Ocean Drilling Program (ODP) Site 1262 on Walvis Ridge (Figure 1) provides a stratigraphically complete upper Maastrichtian record of deep-sea nannofossil ooze for the Southern Atlantic [Zachos et al., 2004]. This allows dating based on orbital cycles, supported by detailed biostratigraphy and magnetostratigraphy. Bulk $\delta^{18} \mathrm{O}$ data from this record [Birch et al., 2016] provide a qualitative sea surface temperature (SST) signal. Correlating the biostratigraphically calibrated record of BJ to the astronomically tuned record of Walvis Ridge provides an excellent opportunity to investigate South Atlantic late Maastrichtian climatic and ecologic changes and their relationship to Deccan Traps outgassing.

\section{Geological Setting}

\subsection{Bajada del Jagüel, Neuquén Basin}

\subsubsection{Geological Setting and Lithology}

The BJ site $\left(38^{\circ} 06^{\prime} 10.5^{\prime \prime} \mathrm{S}, 68^{\circ} 23^{\prime} 20.5^{\prime \prime} \mathrm{W}\right)$ has a paleolatitude of $\sim 43^{\circ} \mathrm{S} \pm 2^{\circ}$ relative to the paleomagnetic reference frame of Torsvik et al. [2012], which is the default frame of paleolatitude.org [van Hinsbergen et al., 2015]. The site is situated in the Neuquén Basin in Argentina. The Neuquén Basin is bordered to the south by the North Patagonian massif and to the northeast by the Sierra Pintada massif (Figure 1). A large transgression from the South Atlantic into the basin [e.g., Bertels, 1979] occurred from the late Maastrichtian to early Danian, during a time of relative tectonic quiescence and low magmatic activity [Malumián and Náñez, 2011]. Mudstones dominating the Maastrichtian and Danian sediments from the Jagüel Formation are homogeneous, nonlaminated, and therefore presumably intensely bioturbated, indicating a reasonably well-oxygenated seafloor [Scasso et al., 2005]. The presence of common bivalves and the rare to common occurrence of planktic foraminifera indicate deposition at midshelf depth [Bertels, 1975; Scasso et al., 2005; Brezina et al., 2014].

A coarse-grained, mottled, clayey sandstone bed, 15-25 cm thick, separates the Maastrichtian and Danian mudstones. This bed can be traced laterally for $5 \mathrm{~km}$ [Scasso et al., 2005]. Vertical, oblique, and horizontal burrows $0.5-1 \mathrm{~cm}$ wide, filled with sand-sized plagioclase grains, shark teeth, and fragments of bivalves, are abundant in the sandstone layer. Based on calcareous nannoplankton data, the base of this sandstone bed represents the K-Pg boundary and is interpreted to have resulted from a tsunami wave, related to the Chicxulub impact event [Scasso et al., 2005]. 


\subsubsection{Paleoenvironment}

During the late Maastrichtian and early Danian, North and Central Patagonia experienced a warm, humid climate. Pollen records suggest rainforests, coastal mangrove forests, and swamp communities in the region [Baldoni, 1992; Kiessling et al., 2005; Barreda and Palazzesi, 2007; Iglesias et al., 2007; Palazzesi and Barreda, 2007]. This vegetation type is classified as megathermal and indicates a minimal average air temperature of $24^{\circ} \mathrm{C}$ [Barreda and Palazzesi, 2007; Palazzesi and Barreda, 2007; Barreda et al., 2012].

Circulation in the Neuquén Basin (Figure 1) was somewhat restricted during the late Maastrichtian and early Danian [Bertels, 1975; Scasso et al., 2005]. Evaporites and mixed carbonate-siliciclastic lithologies in the northernmost part of the Neuquén Basin suggest semiarid conditions and hypersaline conditions in that part of the basin [Barrio, 1990; Kiessling et al., 2006]. The occurrence of salinity stratification in the northwestern part of the Neuquén Basin in the late Maastrichtian is indicated by algae (prasinophytes) suggesting stratified and saline waters [Prámparo et al., 2014]. Abnormalities found in benthic foraminiferal tests from Maastrichtian and Danian records in the basin point toward hypersalinity and/or fluctuations in salinity as well [Ballent and Carignano, 2008]. The central part of the Neuquén Basin, where the BJ site is located, is suggested to have experienced normal marine conditions, evidenced by the presence of planktic foraminifera, dinocysts and relatively few terrestrial palynomorphs [Papú et al., 1996; Prámparo and Papú, 2006].

\subsection{ODP Site 1262 Walvis Ridge}

ODP Site $1262\left(27^{\circ} 11.15^{\prime} \mathrm{S} ; 1^{\circ} 34.62^{\prime} \mathrm{E} ; 4759 \mathrm{~m}\right.$ depth) [Zachos et al., 2004] is located on the northwestern flank of Walvis Ridge, an aseismic ridge and bathymetric high in the SE Atlantic that separates the Cape and Angola basins. The paleolatitude of Walvis Ridge is $\sim 40^{\circ} \mathrm{S} \pm 3^{\circ}$ relative to the paleomagnetic reference frame of Torsvik et al. [2012], which is the default frame of paleolatitude.org [van Hinsbergen et al., 2015] (Figure 1). An upper abyssal paleodepth (2500-3000 m [Alegret and Thomas, 2007]) during the late Maastrichtian to early Paleogene was estimated for the site [Zachos et al., 2004]. The K-Pg boundary interval is considered stratigraphically complete and includes upper Maastrichtian gray-brown clayey nannofossil ooze, and lowermost Danian red-brown clays [Zachos et al., 2004]. The K-Pg boundary is marked by a sharp, but bioturbated irregular surface between these two lithologies. The sequence contains nannofossils and foraminifera throughout [Zachos et al., 2004].

\section{Materials and Methods}

3.1. Bajada del Jagüel, Neuquén Basin

3.1.1. Sampling

Bulk sediment samples from the BJ section were acquired during two field campaigns, in 2012 and 2014. For the present study, high-resolution ( $\mathrm{dm} / \mathrm{cm}$ scale), mostly Maastrichtian sample sets were studied. Danian samples were only studied in low resolution, to provide a general overview across the K-Pg boundary. A $1 \mathrm{~m}$ deep trench was dug to acquire unweathered rock samples, to limit possible contamination by modern soil bacteria. After fresh material was reached, samples were carefully acquired using clean tools. Aliquots of these samples were used for organic geochemical, palynological, and micropaleontological analyses.

3.1.2. TEX $\mathbf{8 6}$ and BIT Analysis

Following standard procedures [Schouten et al., 2002, 2013], 27 aliquot samples were investigated for glycerol dialkyl glycerol tetraethers (GDGTs) at Utrecht University. Briefly, the standard procedures are the following. Organic compounds were extracted from powdered and freeze-dried rock samples of approximately $5 \mathrm{~g}$ with dichloromethane (DCM)/methanol (MeOH) (9:1, vol/vol) using a DIONEX accelerated solvent extractor (ASE 200). The total extracts were separated in four fractions over an activated $\mathrm{Al}_{2} \mathrm{O}_{3}$ column successively using hexane:dichloromethane (DCM) (9:1, vol/vol), ethyl acetate (100\%), DCM:MeOH (95:5, vol/vol), and DCM: $\mathrm{MeOH}(1: 1, \mathrm{vol} / \mathrm{vol})$. After this, $9.9 \mathrm{ng}$ of a $\mathrm{C}_{46}$ GDGT internal standard was added to the DCM:MeOH (95:5, $\mathrm{vol} / \mathrm{vol}$ ) fraction for quantification purposes. All fractions were dried under $\mathrm{N}_{2}$, redissolved in hexaneisopropanol (99:1, vol/vol) and passed over a $0.45 \mu \mathrm{m}$ PTFE filter prior to analysis using an Agilent 1290 Infinity high-performance liquid chromatography (HPLC) coupled to an Agilent 6130 single quad mass spectrometer (MS) following the latest method with improved chromatography [Hopmans et al., 2016]. Subsequently, SSTs were reconstructed using TEX 86 paleothermometry following Schouten et al. [2002] and the transfer function of Kim et al. [2010]. The uncertainty on the calculated temperatures using this method 
is $\pm 2.5^{\circ} \mathrm{C}$ [Kim et al., 2010]. Based on in-house standards, $\mathrm{TEX}_{86}$ reproducibility is better than 0.01 , which translates to less than $0.5^{\circ} \mathrm{C}$ in our temperature range.

The BIT index [Hopmans et al., 2004] was used to estimate the relative contribution of soil vs. marine organic matter in the sample, an indicator for terrestrial influx [Hopmans et al., 2004]. Based on in-house standards, BIT reproducibility is better than 0.03 . For a detailed portrayal of the quality control, including the contribution of methanogenic and methanotrophic archaeal GDGTs, we refer to Text S1 in the supporting information.

\subsubsection{Palynological Analysis}

Forty-three samples from the BJ section were processed following standard palynological processing techniques at the Laboratory of Paleobotany and Palynology at Utrecht University. Approximately $10 \mathrm{~g}$ of each sample were crushed, freeze-dried, $\mathrm{TEX}_{86}^{\mathrm{H}}$ and weighed. The samples were then treated with $10 \% \mathrm{HCl}$ to remove carbonate components and $40 \% \mathrm{HF}$ to dissolve the siliceous components. The residue was sieved over nylon mesh sieves of $250 \mu \mathrm{m}$ and $15 \mu \mathrm{m}$ and submerged in an ultrasound bath for 5 min to break up agglutinated particles. The 15-250 $\mu \mathrm{m}$ fraction of palynological residues was thoroughly mixed, by shaking on a lab dancer. Directly after mixing, slides were made from this fraction. All samples and slides are stored in the collection of the Division of Geology, Department of Earth and Environmental Sciences, KU Leuven, Belgium.

Slides were counted for marine palynomorphs (e.g., dinocysts) up to a minimum of 200 dinocyst specimens per sample. The taxonomy of dinocysts follows Fensome et al. [2008, and references therein]. In addition, a qualitative assessment of terrestrial palynomorphs (e.g., pollen and spores) was made.

To identify major changes in the dinocyst record, morphologically closely related taxa were grouped into complexes using a similar approach as Schiøler et al. [1997], Sluijs and Brinkhuis [2009], and Machalski et al. [2016]. In our study, the following morphological complexes were established: (1) Manumiella spp., grouping all species of Manumiella; (2) Senegalinium complex [cf. Sluijs and Brinkhuis, 2009] lumping all other Peridinioid cysts with a hexaform archeopyle, such as Senegalinium; Cerodinium, and Deflandrea; (3) "coastal taxa," combining all dorsally-ventrally compressed Gonyaulacoid cysts with an apical archeopyle, mainly taxa belonging to the genera Areoligera and Glaphyrocysta, all taxa belonging to Adnatosphaeridium, and all taxa belonging to Hystrichosphaeridium; and (4) "normal marine taxa," which includes all other Gonyaulacoid taxa. This complex is mainly dominated by members of the Spiniferites complex, combining all species of Spiniferites and the morphologically similar genus Achomosphaera. In addition, the percentage coastal taxa relative to normal marine taxa was calculated. A list of taxa assigned to these groups can be found in Table S1 in the supporting information.

Based on correspondence and statistical correlations between palynological records and other proxies, it has been suggested that the Senegalinium complex, an inferred heterotrophic group, was tolerant to increased freshwater input and flourished under high-nutrient conditions [Brinkhuis and Zachariasse, 1988; Sluijs and Brinkhuis, 2009]. Therefore, in this study, abundances of the Senegalinium complex are considered indicative of lower salinities and/or high-nutrient availability.

\subsubsection{Foraminiferal Analysis}

Thirty-eight samples were processed at KU Leuven for foraminiferal studies following standard micropaleontologic procedures. Rock samples were dried in a stove at $50^{\circ} \mathrm{C}$ for at least $24 \mathrm{~h}$. About 10 to $90 \mathrm{~g}$ of dry rock were soaked in a soda solution $\left(50 \mathrm{~g} / \mathrm{I} \mathrm{Na}_{2} \mathrm{CO}_{3}\right)$, depending on the amount of available material. After disintegration, each sample was washed over $2 \mathrm{~mm}$ and $63 \mu \mathrm{m}$ sieves. Representative aliquots of the $125-630 \mu \mathrm{m}$ fraction, containing at least 300 benthic foraminiferal specimens, were obtained using a microsplitter. Picked specimens from this size fraction were permanently stored in Plummer slides. Benthic foraminifera were identified, using the taxonomic works of Cushman [1946], Bertels [1964], and Kellough [1965]. The number of benthic foraminifera per gram dry sediment (Benthic Foraminiferal Number, BFN) and total number of foraminifera per gram (benthic and planktic combined) were calculated using foraminiferal counts and dry sample weight. Percentages planktic foraminifera per sample were calculated relative to the total number of counted foraminifera per sample.

Benthic foraminifera are commonly used as indicators for trophic conditions and bottom water oxygenation [e.g., Jorissen et al., 2007]. Particular foraminiferal morphologies are generally assumed to be characteristic for epibenthic habitats (rounded trochospiral, planoconvex trochospiral, biconvex trochospiral/planispiral, milioline, and tubular morphotypes), whereas others are considered more characteristic for endobenthic habitats (rounded planispiral, flattened ovoid, tapered, and cylindrical) [e.g., Corliss, 1985; Corliss and Chen, 1988]. In 
general, oligotrophic environments are characterized by larger proportions of epibenthic forms, whereas more eutrophic and poorly oxygenated environments are often characterized by larger numbers of endobenthic forms [Jorissen et al., 1995, 2007]. In particular, the endobenthic Buliminacea are indicative for high food supply and poor oxygenation [Jorissen et al., 1995, 2007]. Although assuming such analogues with modern fauna has limitations and shortcomings [Buzas et al., 1993], in this study, the percentages of endobenthic and Buliminacea are used to interpret variations in food supply and oxygenation. In addition, benthic species richness and diversity (see section 3.1.5) as well as benthic indicator taxa are used to estimate paleodepth [e.g., Kellough, 1965; Gibson and Buzas, 1973; Murray, 2006]. Benthic as well as planktic foraminifera show high degrees of recrystallization and are therefore not suitable for stable oxygen isotope analysis.

\subsubsection{Statistical Analysis}

Detrended Correspondence Analysis (DCA) was performed on the Maastrichtian benthic foraminiferal data in order to identify the main changes during this interval. Following Hayek and Buzas [2013], changes in diversity of benthic foraminifera and dinocysts across the studied interval were assessed using the Shannon diversity index $(H)$ and dominance was estimated using the Berger-Parker index (BP). In addition, the number of species or species richness per sample $(S)$ was calculated, accompanied by the number of specimens counted per sample $(N)$ for both benthic foraminifera and dinocysts. Finally, a LOESS (local regression) fit was plotted for all SST data sets with a limited resolution. LOESS is a locally weighted polynomial regression. Useful values of the smoothing parameter $\alpha$ required for LOESS typically lie in the range 0.25 to 0.5 , where a lower $\alpha$ means less smoothing.

\subsection{ODP Site 1262 Walvis Ridge}

\subsection{1. $\delta^{18} 0$ Data Analyses}

In this study, bulk sediment oxygen and carbon isotope data published by Birch et al. [2016] have been used to reconstruct seawater temperature changes. We calculated SSTs using the carbonate-water isotopic temperature derived by Epstein et al. [1953]. In this equation, a past seawater $\delta^{18} \mathrm{O}$ value of $-1.2 \%$ is assumed, representing an ice-free world [Shackleton and Kennett, 1975]. In this study we are concerned with relative changes in temperature, rather than absolute changes. Note that the choice of calibration equation hardly influences such relative temperature changes. For details on the quality assessment of the bulk isotope data, see supporting information (SI) Text S2.

\subsubsection{Age Model}

The K-Pg boundary is known to occur close to an eccentricity minimum [e.g., Kuiper et al., 2008; Westerhold et al., 2008]. Consequently, the $405 \mathrm{kyr}$ eccentricity cycle around the boundary is used as a primary correlation. This is constrained by recent ${ }^{40} \mathrm{Ar} /{ }^{39} \mathrm{Ar}$ dating [Renne et al., 2013], which establishes an age close to 66.0 Ma for the boundary, in agreement with Vandenberghe et al. [2012]. Subsequently, individual short-eccentricity cycles, as identified in ODP Site 1262 and integrated with the land-based section of Zumaia (Spain), were tuned by correlating eccentricity maxima in the records to correlative maxima in the La11 orbital solution [Dinarès-Turell et al., 2014]. Additionally, a preferred astronomical age of $66.0225 \pm 0.0040 \mathrm{Ma}$ for the K-Pg boundary was derived [Dinarès-Turell et al., 2014]. This takes into account the occurrence of the first eccentricity maximum below the K-Pg boundary at four precession cycles below the boundary at Zumaia [Dinarès-Turell et al., 2013] that correlates to an eccentricity maximum in the La11 solution at $66.096 \mathrm{Ma}$.

The time scale for the Maastrichtian part is derived by correlating the short eccentricity cycles as identified at ODP Site 1262 [Westerhold et al., 2008] to the corresponding eccentricity maxima in the La11 orbital solution (Table S2). Westerhold et al. [2008] used X-ray fluorescence (XRF) measurements of iron (Fe) on the spliced record for Site 1262 for the identification of short-eccentricity (100 kyr) cycles. The cyclic variations in Fe content were interpreted by Westerhold et al. [2008] as changes in the amount of clay present in the sediment which in turn was interpreted as an inversed indicator for lysocline depth variations generated by the astronomically driven carbon cycle. The Fe record was filtered by a Gaussian filter to extract the position of 10 eccentricity maxima along the Maastrichtian part analyzed. Westerhold et al. [2008] report the position of these 10 Maastrichtian short eccentricity cycle maxima down to the end of the splice record at about 236 mcd (their Table S3). However, the available Fe data set down to 226.98 mcd only encompasses the youngest five eccentricity cyles $\left(\mathrm{Ma}_{100^{-1}}\right.$ to $\left.\mathrm{Ma}_{100}-5\right)$. All 10 reported Maastrichtian short eccentricity cycles are correlated here to successive eccentricity maxima in the La11 orbital solution to construct the time scale for ODP Site 1262 (Table S2). 


\section{Results}

4.1. Bajada del Jagüel

4.1.1. Biostratigraphy and Age Model Development

Nannofossil biostratigraphy suggests the presence of upper Maastrichtian sediments at the BJ section [Scasso et al., 2005; Keller et al., 2007]. Micula murus (First Appearance Datum (FAD) 69.00 Ma [Anthonissen and Ogg, 2012]) is sparsely present throughout the record [Keller et al., 2007]. Furthermore, Nephrolitus frequens (FAD 67.84 Ma [Anthonissen and Ogg, 2012]) is present throughout the record [Keller et al., 2007]. Yet nannofossil Micula prinsii is absent in the Maastrichtian sediments [Keller et al., 2007]. Micula prinsii, although diachronous, is an excellent biostratigraphic marker for the uppermost Maastrichtian [e.g., Thibault and Husson, 2016]. Its absence could therefore suggest that the uppermost Maastrichtian is missing [Keller et al., 2007]. However, it should be noted that the abundance of $M$. prinsii varies greatly between locations around the globe, sometimes being very rare, or not present at all [e.g., Henriksson, 1993], suggesting an ecological control. Its presence is related to latitude and preservation, occurring most abundantly in midlatitude sites, although its presence or absence cannot always be directly explained [Henriksson, 1993]. The absence of M. prinsii at the study site is therefore not surprising, particularly considering reduced preservation potential in such a semirestricted basin compared to a deep-sea basin.

The uppermost Maastrichtian biostratigraphic planktic foraminifer Plummerita hantkeninoides is also absent at the BJ section [Keller et al., 2007]. Plummerita.hantkeninoides is common in upper Maastrichtian Tethyan sequences [e.g., Speijer and van der Zwaan, 1996] (denoted as P. reicheli), but often rare at other localities, such as in deep-sea environments [e.g., Li and Keller, 1998] and extremely rare in the Gulf Coast sequence of Brazos River, Texas [e.g., Schulte et al., 2006]. In the Neuquén Basin, also other larger open marine planktic foraminifera only occur sparsely [Keller et al., 2007; this study]. Gansserina gansseri, an upper Maastrichtian biostratigraphic marker with a Last Appearance Datum (LAD) at 66.49 Ma [Anthonissen and Ogg, 2012] occurs in one sample, at $14 \mathrm{~m}$ below the K-Pg boundary [Keller et al., 2007], suggesting that this stratigraphic level corresponds to $>0.5 \times 10^{6}$ years before the K-Pg boundary. However, given the rarity to absence of keeled planktic foraminifera above this level, it is likely that this spot occurrence of G. gansseri in the BJ record does not correspond to its LAD. Adverse and variable environmental conditions in the shallow and semirestricted nature of the Neuquén Basin may explain absence of planktic marker taxa as well as many other typical Maastrichtian taxa. Therefore, stratigraphic completeness of the top of the Maastrichtian sequence cannot be confirmed by the usual open marine planktic foraminiferal marker taxa.

Dinocyst biostratigraphic markers found in this study refine the existing biostratigraphy of the BJ section [Keller et al., 2007]. The taxon Disphaerogena carposphaeropsis, which has its approximate FAD at about $1 \times 10^{6}$ years before the K-Pg boundary [De Gracianski et al., 1998; Williams et al., 2004] is present from $14 \mathrm{~m}$ below the K-Pg boundary up to the top of the studied interval. The age derived by the FAD of this taxon is consistent with the age suggested by occurrence of G. gansseri [Keller et al., 2007]. Disphaerogena carposphaeropsis var. cornuta, a marker for the uppermost Maastrichtian and Danian [Prámparo and Papú, 2006; Açıkalın et al., 2015], is present in the upper $13 \mathrm{~m}$ of the Maastrichtian as well (Figure S3). Manumiella seelandica occurs in an acme at $25 \mathrm{~cm}$ below the K-Pg boundary (Figure S3). The acme of this taxon, in some studies denoted as its taxonomic junior synonym M. druggii, is characteristic for the last tens of thousands of years of the Maastrichtian at mid and low latitudes [Habib and Saeedi, 2007; Açıkalın et al., 2015]. This suggests, in contrast to earlier views [e.g., Keller et al., 2007], that the uppermost Maastrichtian is stratigraphically complete within the limits of the biostratigraphic resolution. Moreover, there is no obvious sedimentological evidence for severe hiatuses or changes in sedimentation rates, or for scouring or channeling at the uppermost Maastrichtian, which makes it unlikely that the inferred tsunami wave scoured away much of the uppermost Maastrichtian sediments.

The simultaneous First Occurrences (FOs) of Senoniasphaera inornata, Membranilarnacia tenella, Damassadinium cf. californicum, and Damassadinium californicum at $+7 \mathrm{~cm}$ (Figure S3) indicate that the basal Danian comprises a hiatus or is very condensed. This confirms the findings by Keller et al. [2007], who found that the first Danian planktic foraminifera are present above the sandstone are seven species that characterize subzone P1b (e.g., Parasubbotina pseudobulloides, P. varianta, Parvularugoglobigerina extensa, Globocontusa daubjergensis, Eoglobigerina edita, and Subbotina triloculinoides). The first Danian nannofossil assemblage above the K-Pg boundary indicates zone NP1b, dominated by Paleocene species survivors 


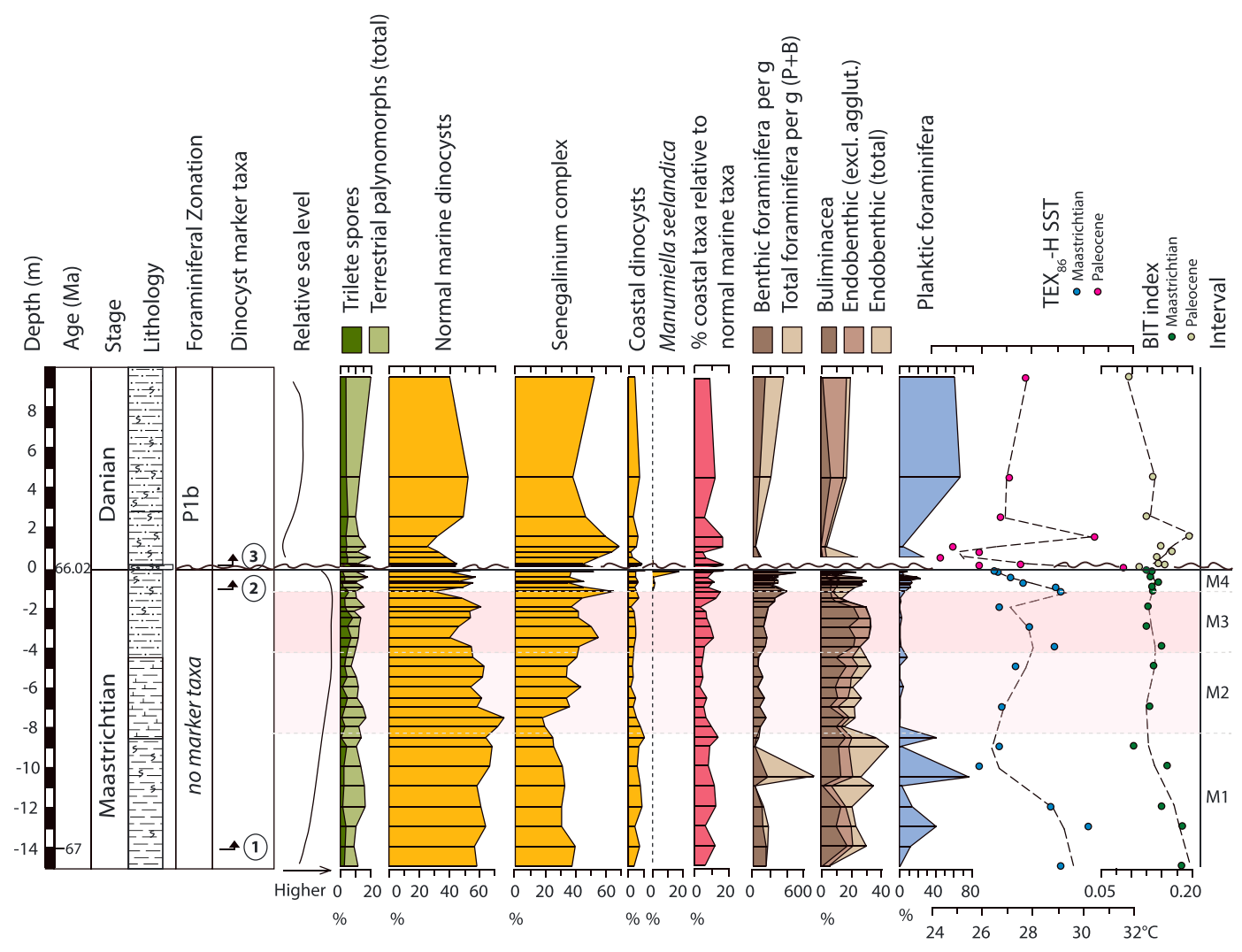

Figure 2. Overview of environmental indicators and interpreted relative sea level changes across the late Maastrichtian to early Danian recorded from BJ. 1: FO Disphaerogena carposphaeropsis; occurrence of G. gansseri [Keller et al., 2007]. 2: Manumiella seelandica acme. 3: FOs of Senoniasphaera inornata, Membranilarnacia tenella, Damassadinium cf. californicum, and Damassadinium californicum. Dotted lines through TEX ${ }_{86}^{H}$ derived SSTs and BIT index data are a LOESS fit $(\alpha=0.3$; Npts = 5). Stratigraphic intervals: see section 4.1.3. Relative sea level as discussed in section 5.2.

such as Thoracosphaera sp., and Braarudosphaera bigelowii [Keller et al., 2007]. Together, this indicates that the lowermost Danian (Zone P0 until Zone P1a) appears to be missing. This would correspond to a missing interval of at least $790 \mathrm{kyr}$ [Vandenberghe et al., 2012].

\subsubsection{General Paleoenvironmental Analyses}

SSTs derived from TEX ${ }_{86}$ values are on average well over $25^{\circ} \mathrm{C}$ (Figure 2), suggesting that a subtropical to tropical climate prevailed in the Neuquén Basin during late Maastrichtian to early Danian. A LOESS fit $(\alpha=0.3$; Npts $=5)$ shows the general underlying trend in the variable SST and BIT index data sets (Figure 2). SSTs fluctuate throughout the record, displaying distinct warming and cooling intervals. The relatively low BIT index $(<0.20)$ suggests that soil-derived GDGTs did not interfere with the marine TEX ${ }_{86}$ SST signal [Weijers et al., 2006]. There are also no signs of significant contributions of methanogenic and methanotrophic archaeal GDGTs (Table S3). TEX 86 and BIT index data can be found in Table S3 in the supporting information.

Palynological samples from the BJ section yield abundant well-preserved palynomorphs, dominated by dinocysts and with minor contributions of acritarchs, prasinophytes, and terrestrial palynomorphs (pollen and spores). The dinocyst associations of the Jagüel Formation (Figure S3) are quite diverse (Figure 3), characteristic for normal marine, shelf conditions [Papú et al., 1996]. In general, the "normal marine" dinocysts, mostly represented by representatives of Spiniferites and the morphologically related genus Achomosphaera, are most abundant in the palynological record, representing $25-75 \%$ of the assemblage. The Senegalinium complex, mostly represented by the genus Senegalinium, also represents an important component of the palynological assemblage, generally $20-60 \%$ of the assemblage. Coastal taxa and Manumiella spp. both represent a minor contribution to the assemblage (generally $<10 \%$ of the assemblage) (Figure 2). All palynological data can be found in Data Set S1 in the supporting information. 


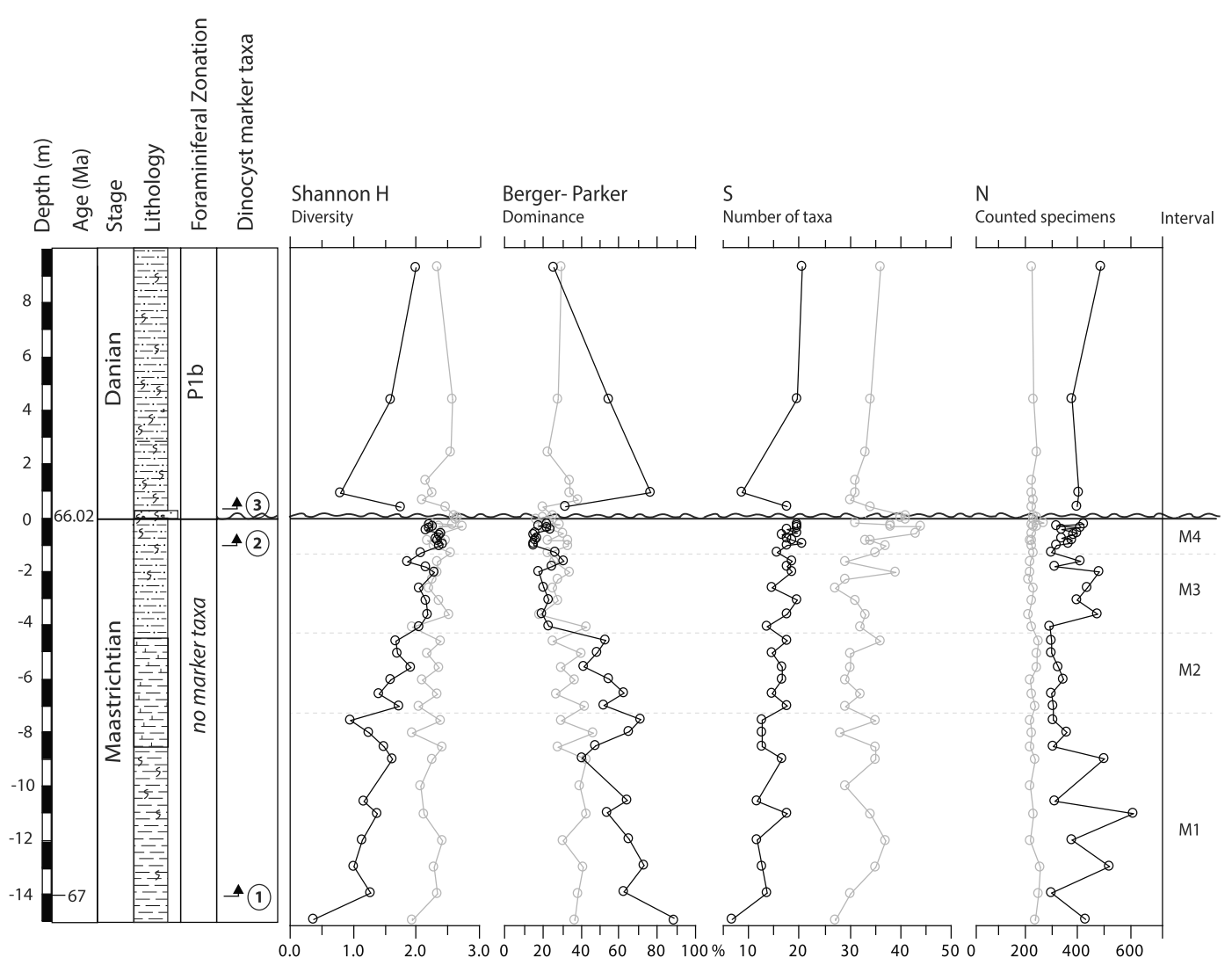

Figure 3. Diversity index (Shannon-H), dominance (Berger-Parker), number of taxa $(S)$, and number of specimens counted for benthic foraminifera (black) and dinocysts (grey) of BJ. For dinocyst marker taxa numbers, see Figure 2. Stratigraphic intervals: see section 4.1.3.

The terrestrial component of the palynological record is mainly dominated by nonsaccate pollen, predominantly represented by Arecaceae (palms), in accordance with the tropical climate indicated by the SST analyses. Bisaccate pollen, mostly represented by Podocarpaceae, are a minor component of the assemblage. Trilete spores, mostly representing ferns, are observed throughout the record, albeit in low abundances (Figure 2).

The benthic foraminiferal record (Figure 54 ) generally shows a low diversity and species richness (on average only 10-20 species per sample), and samples are often dominated by Anomalinoides spp. (Figures 3 and S4). Buliminacea, dominated by Praebulimina kickapooensis, make up $5-25 \%$ of the benthic foraminifera. Endobenthic morphotypes contribute to $10-45 \%$ of the assemblage (Figure 2). Planktic foraminiferal percentages fluctuate strongly and are virtually absent between -400 and $-50 \mathrm{~cm}$ (Figure 2). Where present, Maastrichtian planktic foraminiferal assemblages are dominated by the small, opportunistic taxa Heterohelix and Guembelitria. All foraminiferal data can be found in Data Set S2 in the supporting information. SEM images of most commonly encountered benthic foraminifera can be found in Plates S1 and S2.

4.1.3. Stratigraphic Intervals

A sequence of four stratigraphic intervals was recognized based on the DCA of the investigated Maastrichtian benthic foraminiferal records (Figure 4) and on the dinocyst and geochemical proxy records: -1500 to $-800 \mathrm{~cm}$, (interval M1), $-800 \mathrm{~cm}$ to $-400 \mathrm{~cm}$ (interval M2), -400 to $-120 \mathrm{~cm}$ (interval M3), and $-120 \mathrm{~cm}$ to the K-Pg boundary (interval M4). In the lower Danian record, due to the limited number of samples, no intervals are defined. The SST, BIT index, palynological, and micropaleontological records are presented here according to the sequence of these intervals. A qualitative summary of most important observations during the investigated intervals can be found in Table 1.

\subsubsection{Interval $\mathbf{M} 1$}

The SSTs indicate a cooling from $\sim 30^{\circ} \mathrm{C}$ to $\sim 26.5^{\circ} \mathrm{C}$ in interval M1. Normal marine dinocyst taxa show an increasing trend, from $\sim 55 \%$ to over $75 \%$ of the assemblage, while Senegalinium complex decreases from 


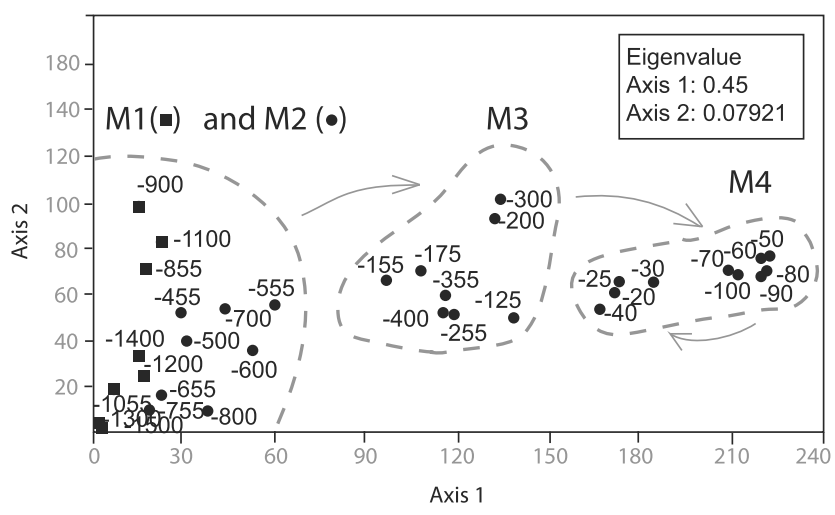

Figure 4. Detrended correspondence analysis of Maastrichtian benthic foraminiferal samples from BJ. Sample numbers represent depth $(\mathrm{cm})$ relative to the K-Pg boundary (base of sandstone bed). Intervals as presented in section 4 are indicated. $\sim 40 \%$ to $\sim 20 \%$ of the assemblage. Throughout this interval, coastal dinocyst taxa represent approximately $5-10 \%$ of the assemblage, where coastal taxa relative to normal marine taxa are approximately $10-15 \%$. The terrestrial palynomorphs fluctuate between 10 and $15 \%$. BIT index values decrease from 0.2 to 0.1 , resulting from a decrease in concentration of branched GDGTs (in ng/g sediment; see Table S3 and Figure 2). This indicates that this variation in BIT index values is caused by a decrease in relative input from land, while marine productivity of GDGTs remains stable. Diversity in benthic foraminiferal and dinocyst assemblages is low, but gradually increases upward, as well as species richness (Figure 3). The interval is dominated by Anomalinoides spp., which mainly consists of Anomalinoides cf. midwayensis. Its dominance decreases gradually upward from approximately 90 to $50 \%$. The relative abundance of endobenthic taxa increases from 5 to $45 \%$ in this interval, while Buliminacea fluctuate between 0 and $15 \%$. BFN are quite low, 100 benthic foraminifera per gram. The relative abundance of planktic foraminifera, mainly dominated by opportunistic Heterohelix and Guembelitria, is generally low $(<10 \%)$ but occasionally peaks to high values ( 40 to 75\%) (Figure 2).

\subsubsection{Interval M2}

A general warming trend is indicated by a slight increase in SSTs, from $\sim 26.5^{\circ} \mathrm{C}$ to $\sim 28^{\circ} \mathrm{C}$ across interval $\mathrm{M} 2$. Normal marine dinocyst taxa drop from $>75 \%$ of the assemblage to $\sim 50 \%$ of the assemblage. Over the same interval, Senegalinium complex shows a strong increase in relative abundance, to over $40 \%$, while coastal taxa decrease to values below 5\%. Coastal taxa relative to normal marine taxa drop to approximately $5-10 \%$. BIT index values increase slightly from 0.1 to 0.15 (Figure 2). Benthic foraminiferal species richness and diversity continue to increase, while dominance decreases (Figure 3). The dominance of Anomalinoides spp., continues to fluctuate between 40 and 70\%. After a sharp drop, endobenthic taxa increase from 15 to $25 \%$ across this interval, while Buliminacea increase from 10 to $15 \%$. Planktic foraminifera are mostly absent in this interval. If present, $\% \mathrm{P}$ is mainly dominated by the opportunistic surface dwelling Heterohelix and Guembelitria.

Table 1. Qualitative Summary of the Most Important Trends (Increase (+) and Decrease (-)) During the Intervals at $B)^{\mathrm{a}}$

\begin{tabular}{|c|c|c|c|c|c|}
\hline & M1 & M2 & M3 & M4 & Danian \\
\hline Temperature & - & + & No trend & - &,-+ \\
\hline Open marine dinoflagellates & + & - & - & No trend &,,-+- \\
\hline Senegalinium complex & - & + & + &,-+ &,,+-+ \\
\hline Coastal dinoflagellates & No trend & - & No trend & No trend & No trend \\
\hline Total terrestrial palynomorphs & No trend & No trend & No trend & No trend &,,+-+ \\
\hline Trilete spores & No trend & No trend & + & - &,+- \\
\hline BIT index & - & + & No trend & No trend &,+- \\
\hline Concentration branched GDGTs (ng/g) & - & No trend & No trend & + &,+- \\
\hline Benthic dominance & - & - & - & Lowest, + &,+- \\
\hline Benthic diversity & + & + & + & Highest, - &,-+ \\
\hline Benthic species richness & + & + & + & Highest, - &,-+ \\
\hline Endobenthics & + & + after drop & Highest, - & + &,-+ \\
\hline Buliminacea & No trend & + & Highest, - & No trend &,,-+- \\
\hline BFN & No trend & No trend & + & No trend &,-+ \\
\hline Planktic foraminifera & Low, peaks & Mostly absent & Mostly absent & + &,-+ \\
\hline
\end{tabular}

${ }^{a}$ When plus and/or minus signs are separated by a comma, these indicate consecutive trends within the interval. 


\subsubsection{Interval $M 3$}

SSTs fluctuate between $\sim 26.5^{\circ} \mathrm{C}$ and $\sim 28.5^{\circ} \mathrm{C}$ across interval $\mathrm{M} 3$. Normal marine dinocyst taxa drop from $50 \%$ to $30 \%$ of the assemblage. Over the same interval, Senegalinium complex increases to over $60 \%$. While total terrestrial palynomorph values remain between 10 and 15\%, trilete spores show a slight increase from 3 to $8 \%$. Coastal taxa relative to normal marine taxa fluctuate between 5 and 15\% (Figure 2). Benthic foraminiferal diversity and species richness continue to increase, while dominance decreases (Figure 3). Anomalinoides spp., is still abundantly present ( $\sim 5$ to $35 \%$ of the assemblage) and frequently dominates the assemblage, but Cibicidoides sp. also frequently dominates the assemblage in this interval ( 15 to $25 \%$ of the assemblage). Buliminacea reach the highest values in the record during this interval ( 25\%) and decrease toward the top of this interval, to values below $10 \%$. Endobenthic taxa reach maximum values of $\sim 35 \%$ but decrease sharply above $\sim-200 \mathrm{~cm}$ as well. BFN gradually increases to $\sim 350$ and $\% \mathrm{P}$ is low throughout (0-5\%) (Figure 2).

\subsubsection{Interval M4}

A cooling trend starts in interval M4, reaching SSTs of $\sim 26^{\circ} \mathrm{C}$ at the top of the interval. Normal marine dinocysts fluctuate around $\sim 50 \%$. The concentration of branched GDGTs (Table S3) increases, Senegalinium complex drops to $\sim 40 \%$, and shows a sharp increase toward the boundary. Terrestrial palynomorph percentages remain between 10 and 15\%, while trilete spore percentages decrease (Figure 2). Benthic foraminiferal diversity and species richness reach their highest values in the record in this interval, while dominance reaches lowest values (Figure 3). Most common taxa in this interval belong to Anomalinoides spp. Buliminacea remain $\sim 5 \%$ while endobenthic morphotypes increase to $\sim 30 \%$ during this interval. BFN remains $\sim 200$ to 300 with one peak value to $\sim 500$. The relative abundances of planktic foraminifera increases slightly, to $\sim 10$ to $20 \%$, and decrease again to $\sim 3$ to $10 \%$ toward the boundary (Figure 2).

\subsubsection{Early Danian Record}

SSTs decrease to $\sim 25^{\circ} \mathrm{C}$ in the first meter above the K-Pg boundary and increase again toward $\sim 27.5^{\circ} \mathrm{C}$ at the top-end of the record. Open marine dinocyst taxa reach their lowest values in the basal meter above the K-Pg boundary $(\sim 15 \%)$ and display an increase until $\sim+5 \mathrm{~m}$, followed by a decrease again toward the top of the record. Senegalinium complex shows an opposite signal, with values up to $70 \%$ in the basal meter above the K-Pg boundary, low values until $\sim+5 \mathrm{~m}$, and increasing values toward the top of the record. Coastal taxa do not show a clear trend in the Danian interval, although coastal taxa relative to marine taxa show highest values in the basal $\sim 2 \mathrm{~m}$ above the sandstone bed. The concentration of branched GDGTs increases in the basal meter above the boundary, resulting in BIT index values increasing toward 0.2. Toward the top of the record, BIT index values decrease again to 0.1, as the concentration of branched GDGTs decreases (see Table S3). In the basal meter above the boundary, percentages terrestrial palynomorphs increase, after which they decrease, until $\sim 3 \mathrm{~m}$ above the K-Pg boundary. Terrestrial palynomorphs increase toward the top of the record. Trilete spores show abundances of $\sim 8 \%$ in the basal $\mathrm{m}$ above the boundary, and they drop again to values of $\sim 5 \%$ at the top of the record (Figure 2).

BFN, benthic diversity, and species richness decrease in the basal meter above the K-Pg boundary, and increase toward the top of the record, while dominance shows the opposite signal. Buliminacea and endobenthics also decrease in the basal meter above the boundary then show an increase, until $\sim 5 \mathrm{~m}$ above the base of the boundary sandstone. Buliminacea decrease again toward the top of the record. Buliminacea remain below $6 \%$ in the entire Danian interval, whereas the endobenthics increase to $20 \%$ towards the top of the record. After an initial decrease in the basal meter above the boundary, \% $\mathrm{P}$ increases toward $\sim 60 \%$ toward the top of the record.

\subsection{Walvis Ridge}

\subsubsection{Age Model}

Our new, astronomically tuned age model (Figure 5) provides absolute ages for the bulk $\delta^{18} \mathrm{O}$ record of Birch et al. [2016]. The studied interval reaches from 67.0685 Ma to 66.0225 Ma (the K-Pg boundary).

\subsubsection{Oxygen Isotope Record}

We plotted SST anomalies with respect to the prewarming interval. From 66.7 Ma onward (700 kyr before the K-Pg boundary), a slight decrease in bulk $\delta^{18} \mathrm{O}$ values indicates a slight warming of the upper water column (Figure 6). Peak warming occurred between 450 and $150 \mathrm{kyr}$ before the boundary, with highest temperatures around $\sim 200 \mathrm{kyr}$ before the boundary. The total decrease in $\delta^{18} \mathrm{O}$ over this entire warming interval is $\sim 0.8 \%$ o, (from 0.1 to $-0.7 \%$ o) which corresponds to a total warming of 3.5 to $4^{\circ} \mathrm{C}$, assuming ice-free conditions. Oxygen and carbon data can be found in Table S4 in the supporting information. 


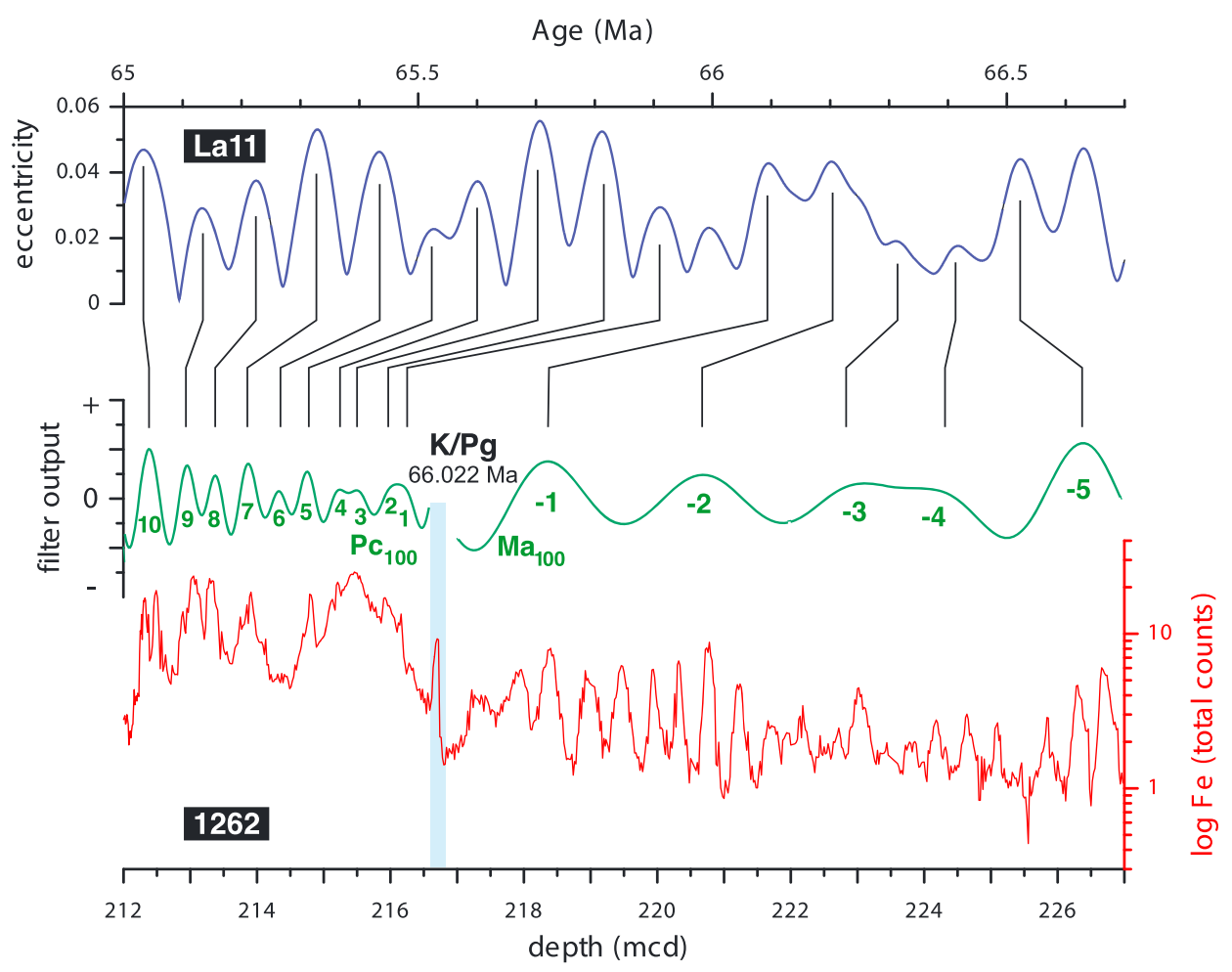

Figure 5. Cyclic variations of the XRF Fe intensity data for sediments from ODP Site 1262 [Westerhold et al., 2008]. The short (green) eccentricity-related cycles have been extracted by Gaussian filtering as in Westerhold et al. [2008] and tuned to the La11 eccentricity solution [Laskar et al., 2011]. A filter at $2.00 \pm 0.60 \mathrm{c} / \mathrm{m}$ is employed along the Maastrichtian interval to extract the eccentricity-related cycles. The available Fe data set down to $226.98 \mathrm{mcd}$ only encompasses the youngest five eccentricity cyles $\left(\mathrm{Ma}_{100^{-1}}\right.$ to $\left.\mathrm{Ma}_{100}-5\right)$. Yet for the interval between 66.7 and $67.0 \mathrm{Ma}$, Westerhold et al. [2008] report the position of five additional Maastrichtian, short eccentricity cycle maxima down to the end of the splice record, at about $236 \mathrm{mcd}$ (their Table S3). The correlation of all 10 successive eccentricity maxima to the La11 orbital solution to construct the time scale for ODP Site 1262 can be found in Table S2.

\section{Discussion}

\subsection{Latest Maastrichtian Climate Change}

To be able to investigate the relationship between these changes and Deccan Trap volcanism and climatic disruption, we compared the biostratigraphically calibrated record of BJ to the astronomically tuned record of Walvis Ridge. While the biostratigraphic constrains of $B J$ do not allow for an exact dating of ecological and environmental changes recorded at this site, they demonstrate that the studied interval roughly covers the last million years of the Cretaceous, at least up to several tens of thousands of years before the K-Pg boundary. Within these constrains, it is possible to tentatively correlate the BJ section with the astronomically tuned record of Walvis Ridge. Therefore, combining these sites allows us to investigate South Atlantic late Maastrichtian climatic and ecological changes and their relationship to Deccan Traps outgassing.

The interval between 67 and 66.7 Ma shows different temperature signals at Walvis Ridge and BJ. Whereas temperatures are relatively stable at Walvis Ridge during this interval, as they are at North Atlantic deepsea sites [Barrera and Savin, 1999], they drop sharply at BJ. The $\sim 3.5^{\circ} \mathrm{C}$ cooling at BJ could be interpreted as a regional signal, possibly as a result of the transgression into the Neuquén Basin. Interestingly, however, a coeval cooling is also observed in shelf deposits of Seymour Island (Figure 6) [Tobin et al., 2012] and across the New Jersey continental margin [Vellekoop et al., 2016]. This suggests that shelf and deep-sea environments responded differently to climate variations during this time interval.

The astronomically tuned bulk $\delta^{18} \mathrm{O}$ record at Walvis Ridge shows that the latest Maastrichtian warming interval started very gradually, at around $66.7 \mathrm{Ma}, \sim 700 \mathrm{kyr}$ before the K-Pg boundary, resulting in a total 
Walvis Ridge (ODP Site 1262)

Bajada del Jagüel

Seymour Island
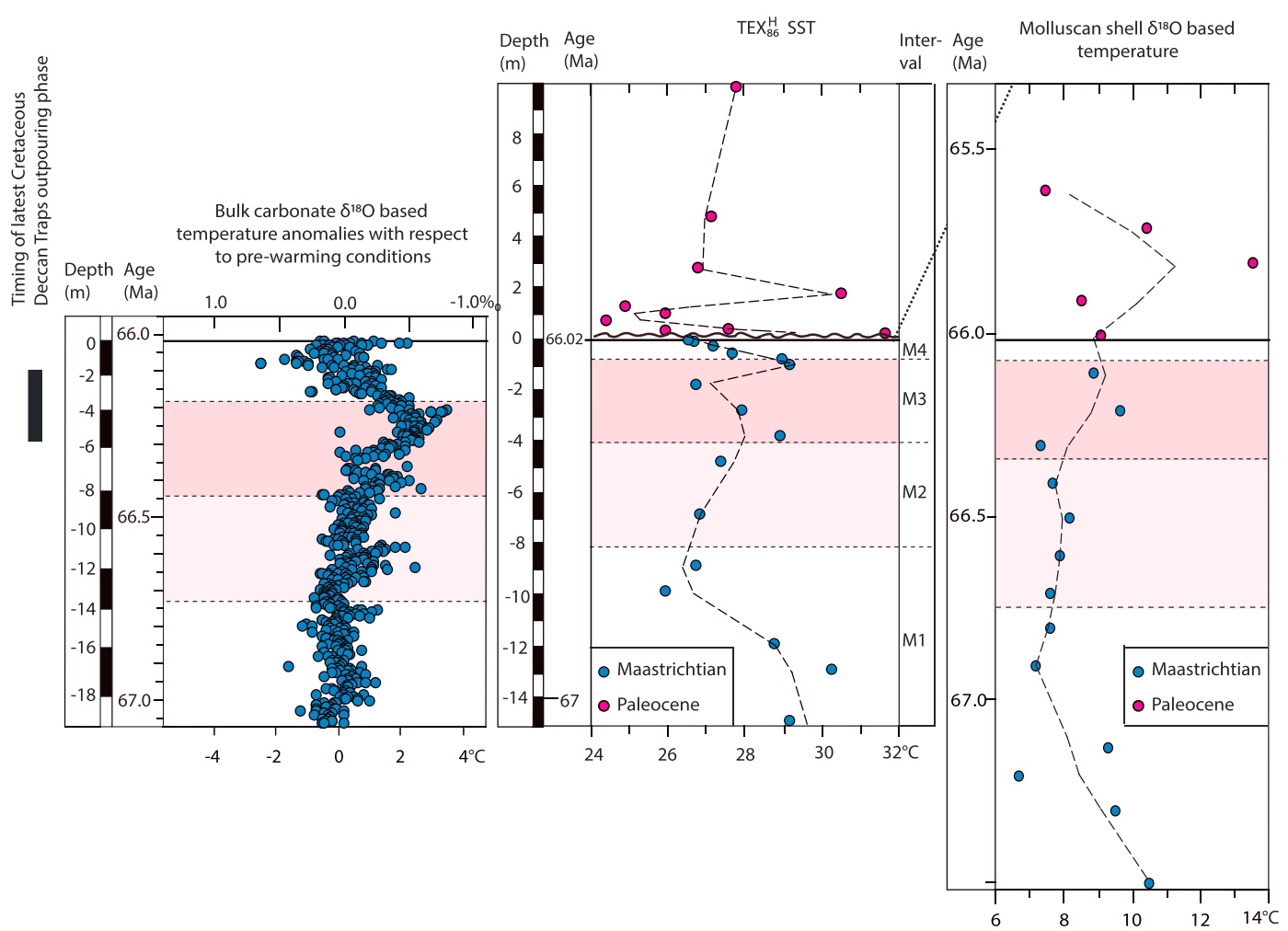

Figure 6. (left) Bulk $\delta^{18} \mathrm{O}$ [Birch et al., 2016] curve of ODP Site 1262 and corresponding temperature anomalies with respect

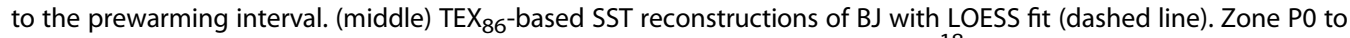
subzone P1a ( 790 kyr) [Vandenberghe et al., 2012] are missing. (right) Mollusk $\delta^{18}$ O-based temperature curves from Seymour Island (modified after Tobin et al. [2012]) with LOESS fit (dashed line). Interval of Deccan Traps outpouring phase (66.288 to 66.1 Ma [Ravizza and Peucker-Ehrenbrink, 2003; Schoene et al., 2015]) is indicated in Figure 6 (left). Red shading tentatively indicates the warming interval.

SST increase of $3.5-4^{\circ} \mathrm{C}$. This early onset of the warming trend was not observed in benthic and planktic deep-sea temperature records [Barrera and Savin, 1999, and references therein] but has been recorded in the TEX ${ }_{86}$ SST records of the New Jersey paleoshelf as well [Vellekoop et al., 2016]. Peak warming at $\sim 450$ to $150 \mathrm{kyr}$ before the end of the Cretaceous at Walvis Ridge concurs with the observed onset and intensity of the warming signal in other marine records [Barrera and Savin, 1999; Olsson et al., 2002; Vellekoop et al., 2016]. The timing of this peak warming coincides with the onset of the latest Cretaceous outpouring phase of the Deccan Traps, at $66.288 \pm 0.027 / 0.047 / 0.085 \mathrm{Ma}$ [Schoene et al., 2015]. The subsequent cooling toward the end of the Cretaceous observed in ODP Site 1262, starting around 150 kyr before the K-Pg boundary, is similar in amplitude to the cooling observed elsewhere [Barrera and Savin, 1999; Olsson et al., 2002; Wilf et al., 2003; Vellekoop et al., 2016].

The absence of an astronomically tuned age model prohibits absolute dating of the BJ section. Yet because ODP Site 1262 is located at nearly the same paleolatitude as BJ, we assume that within the constraints provided by our biostratigraphy of $\mathrm{BJ}$, the temperature records of both sequences can be tentatively correlated. Accordingly, the timing of the gradual warming at BJ, starting $\sim 900 \mathrm{~cm}$ below the K-Pg boundary, is correlated with the onset of warming at $66.7 \mathrm{Ma}$ at Walvis Ridge. Peak warming at $\sim 400-120 \mathrm{~cm}$ below the $\mathrm{K}-\mathrm{Pg}$ boundary at $\mathrm{BJ}$ is thought to correspond to the peak warming at $\sim 450-150 \mathrm{kyr}$ before the $\mathrm{K}-\mathrm{Pg}$ boundary in ODP Site 1262 and elsewhere [Barrera and Savin, 1999; Olsson et al., 2002; Wilf et al., 2003]. Similarly, the cooling trend observed in the top meter of the Maastrichtian at BJ is assumed to have started around $150 \mathrm{kyr}$ before the K-Pg boundary. The rate of climatological change during the Late Maastrichtian was, however, much slower and less severe than the climatologic change following the K-Pg boundary bolide impact, such as the (very) short-lived impact winter following the impact [Vellekoop et al., 2014, 2016]. 


\subsection{Latest Maastrichtian Environmental Response}

Peaks of the inferred opportunistic planktic foraminiferal taxa Guembelitria and Heterohelix indicate an unstable environment [Keller et al., 2007] during the time interval represented by interval M1. High percentages Buliminacea, endobenthics, and Senegalinium complex suggest high-nutrient availability, possibly accompanied by freshwater influx. Together, this implies that during this interval occasional (possibly seasonal) freshwater influx transported nutrients to the basin. The dominance of $A$. midwayensis indicates a shallow environment [Saint-Marc and Berggren, 1988], which is in line with the low benthic foraminiferal diversity and species richness that suggests a shallow, rather restricted environment of $\sim 50 \mathrm{~m}$ depth [Gibson and Buzas, 1973; Murray, 2006]. Relatively high percentages of coastal dinocyst taxa relative to normal marine taxa in this interval confirm this interpretation.

An increasing water depth across intervals $M 1, M 2$, and $M 3$ is indicated by a gradual decrease in dominance of A. midwayensis [Gibson and Buzas, 1973; Saint-Marc and Berggren, 1988] (Figure S4), an increase in benthic foraminiferal diversity and species richness, a decrease in concentration of soil-derived (branched) GDGTs, an increase in normal marine dinocyst taxa, and a decrease in coastal dinocyst taxa (also relative to normal marine taxa) (Figure 2).

During the latest Maastrichtian warming (represented by intervals $M 2$ and $M 3$ ), increasing percentages of Senegalinium complex, an increase in trilete spore percentages and a slight increase in the BIT index suggest an increased terrestrial input into the basin. This terrestrial input likely resulted from enhanced runoff, which possibly led to more permanent salinity stratification, as is also supported by the virtual absence of planktic foraminifera. Enhanced intensity of the hydrological cycle as a result from the latest Maastrichtian warming may have caused the increased freshwater influx. In addition to a decreased salinity, the riverine influx probably led to an increased transport of nutrients toward the basin, as is suggested for instance by increased Senegalinium complex percentages.

It could be argued that the palynological and planktic foraminiferal observations in intervals M2 and M3 reflect a sea level fall instead of an increased freshwater and nutrient influx. However, increased Buliminacea and BFN during this interval rather support the freshwater-driven nutrient influx hypothesis. Furthermore, the low abundance of coastal taxa supports a higher sea level as well. In conclusion, the combined foraminiferal and palynological observations suggest that increased nutrient levels in the water column resulted in an enhanced primary production and flux of organic matter to the seafloor.

The relatively low total organic carbon (TOC) values [Keller et al., 2007], the bioturbated sediments, and moderate endobenthic percentages suggest that the inferred salinity stratification and increase in organic matter flux did not lead to anoxia at the seafloor. Furthermore, the response to the environmental changes at $\mathrm{BJ}$ is rather limited, especially when compared to the major benthic foraminiferal assemblage changes observed at the K-Pg boundary at many sites worldwide [e.g., Olsson et al., 2002; Culver, 2003; Alegret and Thomas, 2005; Woelders and Speijer, 2015]. It remains uncertain to which extent latest Maastrichtian environmental changes contributed directly to the K-Pg boundary mass extinction.

A cooling trend during the last $\sim 150 \mathrm{kyr}$ of the Cretaceous (interval M4) resulted in more arid conditions in land areas adjacent to the Neuquén Basin, as is suggested by the drop in Senegalinium complex and trilete spore percentages. In addition, the reappearance of planktic foraminifera and the increase in normal marine dinocyst percentages indicate increased salinity of the surface waters, which points toward a reduced freshwater influx as well. The drop in Buliminacea percentages and low dominance in the benthic foraminiferal record indicate a decrease in nutrient supply to the seafloor and better oxygenation during this cooling interval. The decreasing benthic foraminiferal diversity, increasing abundance of $A$. midwayensis and increasing concentration of soil-derived GDGTs, coinciding with a relatively high proportion of coastal dinocyst taxa suggest that sea level was falling simultaneously.

\subsection{Implications for Latest Maastrichtian Continental Climate Change}

The concurrent warm and wet climate phase in between two cooler and dry phases suggests a positive link between Deccan Traps-induced atmospheric warming and an enhanced hydrological cycle in northern Patagonia. In the present day, this region is characterized by a semiarid climate, with a summer precipitation maximum [Vera et al., 2006] and a long, dry, and cold winter. The summer precipitation peak results from strong summer surface heating, convection, and latent heat release over tropical South America [Vera 
et al., 2006]. This continental warming gives rise to a large temperature contrast between continent and ocean, which leads to the formation of a thermal low-pressure system over the continent [Villalba et al., 1998]. During summer, when the thermal low peaks in strength and size, it allows for transport of warm and moist air masses all the way to Northern Argentina, where these invoke enhanced summer rainfall.

Tree ring data [Villalba et al., 1998] as well as climate model sensitivity studies indicate that in warmer (greenhouse) climates, also in the Cretaceous [Bush and Philander, 1997; Labraga, 1997; Vera et al., 2006], the thermal low over the continent expands, strengthens, and moves poleward, enhancing precipitation over the area where the Neuquén Basin is located. A similar mechanism could explain the increased hydrological cycle in BJ during the latest Maastrichtian Deccan Traps outpouring phase. Although the Andes mountain range was possibly less pronounced during the latest Maastrichtian [Tunik et al., 2010], the geography of the South American continent, as well as large-scale atmospheric patterns [Bush and Philander, 1997; Compagnucci, 2011], were similar to those of present day, suggesting that similar precipitation seasonality existed. This indicates that the enhanced freshwater availability in the Neuquén Basin during the warm period of the latest Maastrichtian could be explained by a more active thermal low in summer. It should be noted, however, that the impact of such large-scale mechanisms is modulated by local meteorological phenomena, which are under influence of local topography and distance to the sea.

We speculate that this mechanism was not restricted to the South American continent. Other large continents, such as Africa, Australia, Asia, and North America, are also characterized by seasonal, monsoon-like precipitation pulses at midlatitudes that are driven by land-sea temperature contrasts and by similar thermally driven circulation cells [e.g., Johnson et al., 2016]. Hence, while terrestrial data on precipitation changes in the latest Maastrichtian are nearly absent, making it difficult to corroborate this hypotheses, we suggest that the enhanced hydrological cycle in the latest Maastrichtian is not unique to our site, but might be shared by many midlatitudinal, continental sites.

\section{Conclusion}

Our results show that the latest Maastrichtian warming occurred between $\sim 700$ and 150 kyr before the Chicxulub impact. Peak warming occurred between $\sim 450$ and $150 \mathrm{kyr}$, before the K-Pg boundary, coinciding with the Latest Cretaceous Deccan Traps outpouring phase. The magnitude of the warming was $\sim 2.5$ to $3^{\circ} \mathrm{C}$ at BJ and $\sim 3.5$ to $4^{\circ} \mathrm{C}$ at ODP Site 1262 compared to prewarming temperatures. Although the early, gradual onset at around $700 \mathrm{kyr}$ before the K-Pg boundary was not observed in other deep-sea temperature proxy records, it is similar to published records from the Seymour Island and New Jersey shelves [Tobin et al., 2012; Vellekoop et al., 2016]. The latest Maastrichtian warming interval was followed by a gradual cooling towards the end of the Cretaceous.

Acknowledgments
Supporting data, texts, and figures are included in SI files; any additional data may be obtained from L.W. (e-mail: lineke.woelders@gmail.com). Data already published in literature are properly cited and referred to in the reference list. Samples and data provided by the Ocean Drilling Program (ODP) and International Ocean

Discovery Program (IODP) were used. Universidad Nacional de Río Negro and CONICET partially funded the field work at the BJ site. Funding to this project was provided by the Research Foundation Flanders (FWO) to R.P.S. (G.0B85.13). This work was also carried out within the theme of the Netherlands Earth System Science Centre (NESSC), financially supported by the Ministry of Education, Culture and Science (OCW). NWO grant 834.11.006 enabled the purchase of the UHPLC-MS system used for GDGT analyses at UU. Gert-Jan Reichart and two anonymous reviewers are thanked for their valuable

comments. L. Woelders and J. Vellekoop contributed equally to the research and are both considered first authors.

During the latest Maastrichtian warming interval, the thermal low over the South American continent likely expanded, strengthened, and moved poleward, which enhanced precipitation over the area where the Neuquén Basin is located. The enhanced precipitation resulted in increased riverine input in the basin and salinity stratification. We speculate that this mechanism may not have been restricted to the South American continent. During the following cooling trend toward the K-Pg boundary the salinity stratification dissipated again under more arid conditions at this site. Late Maastrichtian benthic foraminiferal and dinoflagellate changes in response to these environmental changes at BJ are nevertheless rather limited, especially when compared to the major assemblage turnovers observed at many K-Pg boundary sites worldwide. This suggests that environmental perturbations during the latest Maastrichtian warming event were less severe than those resulting from the K-Pg boundary bolide impact. Nevertheless, such preimpact changes might have resulted in ecosystem stress, making the ecosystem more vulnerable to the detrimental effects of the Chicxulub impact.

\section{References}

Abramovich, S., S. Yovel-Corem, A. Almogi-Labin, and C. Benjamini (2010), Global climate change and planktic foraminiferal response in the Maastrichtian, Paleoceanography, 25, PA2201, doi:10.1029/2009PA001843.

Açıkalın, S., et al. (2015), Geochemical and palaeontological characterization of a new K-Pg boundary locality from the northern branch of the Neo-Tethys: Mudurnu-Göynük Basin, NW Turkey, Cretac. Res., 52, 251-267, doi:10.1016/j.cretres.2014.07.011.

Alegret, L., and E. Thomas (2005), Cretaceous/Paleogene boundary bathyal paleo-environments in the central North Pacific (DSDP Site 465), the Northwestern Atlantic (ODP Site 1049), the Gulf of Mexico and the Tethys: The benthic foraminiferal record, Palaeogeogr. Palaeoclimatol. Palaeoecol., 224(1-3), 53-82, doi:10.1016/j.palaeo.2005.03.031. 
Alegret, L., and E. Thomas (2007), Deep-sea environments across the Cretaceous/Paleogene boundary in the eastern South Atlantic Ocean (ODP Leg 208, Walvis Ridge), Mar. Micropaleontol., 64(1-2), 1-17, doi:10.1016/j.marmicro.2006.12.003.

Alvarez, L., W. Alvarez, F. Asaro, and H. V. Michel (1980), Extraterrestrial cause for the Cretaceous-Tertiary extinction, Science, 208(4448), 1095-1108.

Anthonissen, D. E., and J. G. Ogg (2012), Cenozoic and Cretaceous biochronology of planktonic foraminifera and calcareous nannofossils, in The Geologic Time Scale 2012, edited by F. M. Gradstein et al., pp. 1083-1128, Elsevier, Boston.

Archibald, J. D., et al. (2010), Cretaceous extinctions: Multiple causes, Science, 328(5981), 973, doi:10.1126/science.328.5981.973-a.

Arregui, C., O. Carbone, and H. A. Leanza (2011), Contexto tectosedimentario, in Geología y Recursos Naturales de la Provincia de Neuquén: XVIII Congreso Geológico Argentino, edited by H. A. Leanza et al., pp. 29-36, Asociación Geológica Argentina, Buenos Aires.

Baldoni, A. M. (1992), Palynology of the lower Lefipán formation (Upper Cretaceous) of Barranca de Los Perros, Chubut Province, Argentina. Part I, cryptogam spores and gymnosperm pollen, Palynology, 16, 117-136, doi:10.1080/01916122.1992.9989410.

Ballent, S. C., and A. P. Carignano (2008), Morphological abnormalities in late Cretaceous and early Paleocene foraminifer tests (northern Patagonia, Argentina), Mar. Micropaleontol., 67(3-4), 288-296, doi:10.1016/j.marmicro.2008.02.003.

Barreda, V., and L. Palazzesi (2007), Patagonian vegetation turnovers during the Paleogene-early Neogene: Origin of arid-adapted floras, Bot. Rev., 73(1), 31-50.

Barreda, V. D., N. R. Cúneo, P. Wilf, E. D. Currano, R. A. Scasso, and H. Brinkhuis (2012), Cretaceous/Paleogene floral turnover in Patagonia: Drop in diversity, low extinction, and a Classopollis spike, PLoS One, 7(12), e52455, doi:10.1371/journal.pone.0052455.

Barrera, E., and S. M. Savin (1999), Evolution of late Campanian-Maastrichtian marine climates and oceans, in Evolution of the Cretaceous Ocean-Climate System, Geol. Soc. Am. Spec Pap., vol. 332, edited by E. Barrera and E. Johnson, pp. 245-282, Boulder, Colo.

Barrio, C. A. (1990), Paleogeographic control of upper cretaceous tidal deposits. Neuquén Basin, Argentina, J. South Am. Earth Sci., 3(1), 31-49.

Bertels, A. (1964), Micropaleontología del Paleoceno de General Roca, provincia de Río Negro, Rev. del Mus. La Plata, Nueva Ser. Paleontol., 4(23), 125-184.

Bertels, A. (1975), Upper Cretaceous (Middle Maastrichtian) ostracodes of Argentina, Micropaleontology, 21(1), 97-130, doi:10.2307/1485157. Bertels, A. (1979), Paleobiogeografía de los Foraminíferos del Cretácico superior y Cenozoico de America del Sur, Ameghiniana, 16, $273-356$.

Birch, H. S., H. K. Coxall, P. N. Pearson, D. Kroon, and D. N. Schmidt (2016), Partial collapse of the marine carbon pump after the CretaceousPaleogene boundary, Geology, 44(4), 287-290, doi:10.1130/G37581.1.

Boucot, A. J., C. Xu, R. J. Morley, and C. R. Scotese (2013), Phanerozoic paleoclimate: An atlas of lithologic indicators of climate, in Phanerozoic Paleoclimate: Concepts in Sedimentology and Paleontology, vol. 11, edited by G. J. Nichols and B. Ricketts, pp. 1-18, SEPM, Tulsa.

Brezina, S., M. V. Romero, S. Casadío, and C. Bremec (2014), Boring polychaetes associated with Pycnodonte (Phygraea) vesicularis (lamarck) from the Upper Cretaceous of Patagonia. A case of commensalism?, Ameghiniana, 51, 129-140.

Brinkhuis, H., and W. J. Zachariasse (1988), Dinoflagellate cysts, sea level changes and planktonic foraminifers across the Cretaceous-Tertiary boundary at El Haria, northwest Tunisia, Mar. Micropaleontol., 13(2), 153-191, doi:10.1016/0377-8398(88)90002-3.

Brugger, J., G. Feulner, and S. Petri (2016), Baby, it's cold outside: Climate model simulations of the effects of the asteroid impact at the end of the Cretaceous, Geophys. Res. Lett., 44, 419-427, doi:10.1002/2016GL072241.

Bush, A. B. G., and S. G. H. Philander (1997), The Late Cretaceous: Simulation with a coupled atmosphere-ocean GCM, Paleoceanography, 21, 475-516.

Buzas, M. A., S. J. Culver, and F. J. Jorissen (1993), A statistical evaluation of the microhabitats of living (stained) infaunal benthic foraminifera, Mar. Micropaleontol., 20(3-4), 311-320, doi:10.1016/0377-8398(93)90040-5.

Chumakov, N. M., M. A. Zharkov, A. B. Herman, M. P. Doludenko, N. N. Kalandadze, E. L. Lebedev, A. G. Ponomarenko, and A. S. Rautian (1995)، Climatic zones in the middle of the Cretaceous Period, Stratigr. Geol. Correl., 3, 3-14.

Compagnucci, R. H. (2011), Atmospheric circulation over Patagonia from the Jurassic to present: A review through proxy data and climatic modelling scenarios, Biol. J. Linn. Soc., 103(2), 229-249, doi:10.1111/j.1095-8312.2011.01655.x

Corliss, B. H. (1985), Microhabitats of benthic foraminifera within deep-sea sediments, Nature, 314, 435-438, doi:10.1038/314435a0.

Corliss, B. H., and C. Chen (1988), Morphotype patterns of Norwegian Sea deep-sea benthic foraminifera and ecological implications, Geology, 16(8), 716-719.

Culver, S. J. (2003), Benthic foraminifera across the Cretaceous-Tertiary (K-T) boundary: A review, Mar. Micropaleontol., 47, 177-226.

Cushman, J. A. (1946), Upper Cretaceous foraminifera of the Gulf Region of the United States and adjacent areas, Geol. Surv. Prof. Pap. 206.

Dinarès-Turell, J., V. Pujalte, K. Stoykova, and J. Elorza (2013), Detailed correlation and astronomical forcing across the Upper Maastrichtian succession from the Basque Basin, Bol. Geol. y Min., 124, 253-282.

Dinarès-Turell, J., T. Westerhold, V. Pujalte, U. Röhl, and D. Kroon (2014), Astronomical calibration of the Danian stage (early Paleocene) revisited: Settling chronologies of sedimentary records across the Atlantic and Pacific Oceans, Earth Planet. Sci. Lett., 405, 119-131, doi:10.1016/j.epsl.2014.08.027.

Epstein, S., H. Buchsbaum, H. A. Lowenstam, and H. C. Urey (1953), Variation of $\mathrm{O}^{18}$ content of waters from natural sources, Bull. Geol. Soc. Am., $64,1315-1326$

Fensome, R. A., R. A. MacRae, and G. L. Williams (2008), DINOFLAJ2, version 1. American Association of Stratigraphic Palynologists, Data Series no., 1.

Folguera, A., M. Spagnuolo, E. Rojas Vera, V. Litvak, D. Orts, and V. Ramos (2011), Magmatismo Neógeno y Cuaternario, in Geología y Recursos Naturales De La Provincia de Neuquén: XVIII Congreso Geológico Argentino, edited by H. A. Leanza et al., pp. 275-286, Asociación Geológica Argentina, Buenos Aires.

Gibson, G., and A. Buzas (1973), Species diversity: Patterns in modern and Miocene foraminifera of the eastern margin of North America, Geol. Soc. Am. Bull., 84, 217-238.

De Gracianski, P. C., J. Hardenbol, T. Jacquin, and P. R. Vail (1998) Mesozoic-Cenozoic Sequence Stratigraphy of European Basins, vol. 60,786 pp., Soc. of Econ. Paleontol. and Mineral. Spec. Publ., Tulsa.

Habib, D., and F. Saeedi (2007), The Manumiella seelandica global spike: Cooling during regression at the close of the Maastrichtian, Palaeogeogr. Palaeoclimatol. Palaeoecol., 255(1-2), 87-97, doi:10.1016/j.palaeo.2007.02.043.

Hayek, L. A. C., and M. A. Buzas (2013), On the proper and efficient use of diversity measures with individual field samples, J. Foraminifer. Res., 43(3), 305-313, doi:10.2113/gsjfr.43.3.305.

Henehan, M. J., P. M. Hull, D. E. Penman, J. W. B. Rae, and D. N. Schmidt (2016), Biogeochemical significance of pelagic ecosystem function: An end-Cretaceous case study, Philos. Trans. R. Soc. B, 371(20150510), doi:10.1098/rstb.2015.0510.

Henriksson, A. (1993), Biochronology of the terminal Cretaceous calcareous nannofossil zone of Micula prinsii, Cretac. Res., 14, 59-68.

Hopmans, E. C., J. W. H. Weijers, E. Schefuß, L. Herfort, J. S. Sinninghe Damsté, and S. Schouten (2004), A novel proxy for terrestrial organic matter in sediments based on branched and isoprenoid tetraether lipids, Earth Planet. Sci. Lett., 224(1-2), 107-116, doi:10.1016/ j.epsl.2004.05.012. 
Hopmans, E. C., S. Schouten, and J. S. Sinninghe Damsté (2016), The effect of improved chromatography on GDGT-based palaeoproxies, Org. Geochem., 93, 1-6, doi:10.1016/j.orggeochem.2015.12.006.

Iglesias, A., P. Wilf, K. R. Johnson, A. B. Zamuner, N. R. Cúneo, S. D. Matheos, and B. S. Singer (2007), A Paleocene lowland macroflora from Patagonia reveals significantly greater richness than North American analogs, Geology, 35(10), 947-950.

Johnson, T. C., et al. (2016), A progressively wetter climate in southern East Africa over the past 1.3 million years, Nature, 537(7619), 220-224.

Jorissen, F. J., H. C. de Stigter, and J. G. V. Widmark (1995), A conceptual model explaining benthic foraminiferal microhabitats, Mar. Micropaleontol., 26(1-4), 3-15, doi:10.1016/0377-8398(95)00047-X.

Jorissen, F. J., C. Fontanier, and E. Thomas (2007), Paleoceanographical proxies based on deep-sea benthic foraminiferal assemblage characteristics, in Proxies in Late Cenozoic Paleoceanography: Pt. 2: Biological Tracers and Biomarkers, edited by C. Hillaire-Marcel and A. de Vernal, pp. 263-326, Elsevier, Amsterdam, doi:10.1016/S1572-5480(07)01012-3.

Keller, G., T. Adatte, A. Tantawy, Z. Berner, W. Stinnesbeck, D. Stueben, and H. Leanza (2007), High stress late Maastrichtian-Early Danian palaeoenvironment in the Neuquén Basin, Argentina, Cretac. Res., 28(6), 939-960, doi:10.1016/j.cretres.2007.01.006.

Keller, G., J. Punekar, and P. Mateo (2016), Upheavals during the Late Maastrichtian: Volcanism, climate and faunal events preceding the end-Cretaceous mass extinction, Palaeogeogr. Palaeoclimatol. Palaeoecol., 441, 137-151, doi:10.1016/j.palaeo.2015.06.034.

Kellough, G. R. (1965), Paleoecology of the foraminiferida of the Wills Point Formation (Midway Group) in Northeast Texas, Trans. Gulf Coast Assoc. Geol. Soc., 15, 73-153.

Kemp, D. B., S. A. Robinson, J. A. Crame, J. E. Francis, J. Ineson, R. J. Whittle, V. C. Bowman, and C. O'Brien (2014), A cool temperate climate on the Antarctic Peninsula through the latest Cretaceous to early Paleogene, Geology, 42(7), 583-586, doi:10.1130/G35512.1.

Kiessling, W., E. Aragón, R. Scasso, M. Aberhan, J. Kriwet, F. Medina, and D. Fracchia (2005), Massive corals in Paleocene siliciclastic sediments of Chubut (Argentina), Facies, 51(1-4), 233-241, doi:10.1007/s10347-005-0023-3.

Kiessling, W., R. Scasso, M. Aberhan, L. Ruiz, and S. Weidemeyer (2006), A Maastrichtian microbial reef and associated limestones in the Roca Formation of Patagonia (Neuquén Province, Argentina), Foss, Rec. - Mitteilungen aus dem Museum für Naturkd., 9(2), 183-197, doi:10.1002/ mmng.200600007.

Kim, J. H., J. van der Meer, S. Schouten, P. Helmke, V. Willmott, F. Sangiorgi, N. Koç, E. C. Hopmans, and J. S. Sinninghe Damsté (2010), New indices and calibrations derived from the distribution of crenarchaeal isoprenoid tetraether lipids: Implications for past sea surface temperature reconstructions, Geochim. Cosmochim. Acta, 74(16), 4639-4654, doi:10.1016/j.gca.2010.05.027.

Kring, D. A. (2007), The Chicxulub impact event and its environmental consequences at the Cretaceous-Tertiary boundary, Palaeogeogr. Palaeoclimatol. Palaeoecol., 255(1-2), 4-21, doi:10.1016/j.palaeo.2007.02.037.

Kuiper, K. F., A. Deino, F. J. Hilgen, W. Krijgsman, P. R. Renne, and J. R. Wijbrans (2008), Synchronizing rock clocks of Earth history, Science, 320, 500-504, doi:10.1126/science.1154339.

Labraga, J. C. (1997), The climate change in South America due to a doubling in the $\mathrm{CO}_{2}$ concentration: Intercomparison of general circulation model equilibrium experiments, Int. J. Climatol., 17(4), 377-398.

Laskar, J., M. Gastineau, J.-B. Delisle, A. Farres, and A. Fienga (2011), Strong chaos induced by close encounters with Ceres and Vesta, Astron. Astrophys., 532, L4, doi:10.1051/0004-6361/201117504.

Li, L., and G. Keller (1998), Abrupt deep-sea warming at the end of the Cretaceous, Geology, 26(11), 995-998.

Machalski, M., J. Vellekoop, Z. Dubicka, D. Peryt, and M. Harasimiuk (2016), Late Maastrichtian cephalopods, dinoflagellate cysts and foraminifera from the Cretaceous-Paleogene succession at Lechówka, southeast Poland: Stratigraphic and environmental implications, Cretac. Res., 57, 208-227, doi:10.1016/j.cretres.2015.08.012.

Malumián, N., and C. Náñez (2011), The Late Cretaceous-Cenozoic transgressions in Patagonia and the Fuegian Andes: Foraminifera, palaeoecology, and palaeogeography, Biol. J. Linn. Soc., 103(2), 269-288, doi:10.1111/j.1095-8312.2011.01649.x.

Ménot, G., E. Bard, F. Rostek, J. Weijers, E. Hopmans, S. Schouten, and J. Sinninghe Damsté (2006), Early reactivation of European rivers during the last deglaciation, Science, 313(5793), 1623-1625, doi:10.1126/science.1130511.

Murray, J. W. (2006), Ecology and Applications of Benthic Foraminifera, 426 pp., Cambridge Univ. Press, Cambridge.

Nordt, L., S. Atchley, and S. Dworkin (2003), Terrestrial evidence for two greenhouse events in the latest Cretaceous, GSA Today, 13(12), 4-9.

Olsson, R. K., J. D. Wright, and K. G. Miller (2001), Paleobiogeography of Pseudotextularia elegans during the latest Maastrichtian global warming event, J. Foraminifer. Res., 31(3), 275-282.

Olsson, R. K., K. G. Miller, J. V. Browning, J. D. Wright, and B. S. Cramer (2002), Sequence stratigraphy and sea-level change across the Cretaceous-Tertiary boundary on the New Jersey passive margin, in Catastrophic Events and Mass Extinctions: Impacts and Beyond, edited by C. Koeberl and K. G. Macleod, 356, 97-108.

Palazzesi, L., and V. Barreda (2007), Major vegetation trends in the Tertiary of Patagonia (Argentina): A qualitative paleoclimatic approach based on palynological evidence, Flora-morphology, Distrib. Funct. Ecol. Plants, 202(4), 328-337.

Papú, O. H., M. B. Prámparo, C. Náñez, and A. Concheyro (1996), Palinología y micropaleontología de la formación Jagüel (MaastrichtianoDaniano), perfil Opaso, Cuenca Neuquina, Arentina, in Simposio Paleogeno de América del Sur Buenos Aires. Actas Subsecretaria de Mineria de la Nación, Anales, vol. 33, pp. 17-31, Servicio Geológico Minero Argentino, Buenos Aires.

Petersen, S. V., A. Dutton, and K. C. Lohmann (2016), End-Cretaceous extinction in Antarctica linked to both Deccan volcanism and meteorite impact via climate change, Nat. Commun., 7, 12079.

Prámparo, M. B., and O. H. Papú (2006), Late Maastrichtian dinoflagellate cysts from the Cerro Butaló section, southern Mendoza province, Argentina, J. Micropaleontol., 25, 23-33.

Prámparo, M. B., A. L. Cione, and B. Gonzalez Riga (2014), Sharks (Neoselachii) and palynomorphs from Mendoza (Argentina): New evidence of the Late Cretaceous Atlantic marine transgression, Alcheringa An Australas, J. Palaeontol., 38(2), 177-189, doi:10.1080/03115518.2014.849027.

Punekar, J., G. Keller, H. M. Khozyem, T. Adatte, E. Font, and J. Spangenberg (2016), A multi-proxy approach to decode the end-Cretaceous mass extinction, Palaeogeogr. Palaeoclimatol. Palaeoecol., 441, 116-136, doi:10.1016/j.palaeo.2015.08.025.

Ravizza, G., and B. Peucker-Ehrenbrink (2003), Chemostratigraphic evidence of Deccan volcanism from the marine osmium isotope record, Science, 302(5649), 1392-1395, doi:10.1126/science.1089209.

Renne, P. R., A. L. Deino, F. J. Hilgen, K. F. Kuiper, D. F. Mark, W. S. Mitchell, L. E. Morgan, R. Mundil, and J. Smit (2013), Time scales of critical events around the Cretaceous-Paleogene boundary, Science, 339(6120), 684-687, doi:10.1126/science.1230492.

Richards, M. A., W. Alvarez, S. Self, L. Karlstrom, P. R. Renne, M. Manga, C. J. Sprain, J. Smit, L. Vanderkluysen, and S. A. Gibson (2015), Triggering of the largest Deccan eruptions by the Chicxulub impact, Geol. Soc. Am. Bull., doi:10.1130/B31167.1.

Saint-Marc, P., and W. A. Berggren (1988), A quantitative analysis of Paleocene benthic foraminiferal assemblages in central Tunisia, J. Foraminifer. Res., 18, 97-113.

Scasso, R. A., A. Concheyro, W. Kiessling, M. Aberhan, L. Hecht, F. A. Medina, and R. Tagle (2005), A tsunami deposit at the Cretaceous/Paleogene boundary in the Neuquén Basin of Argentina, Cretac. Res., 26(2), 283-297, doi:10.1016/j.cretres.2004.12.003. 
Scasso, R. A., M. Aberhan, L. Ruiz, S. Weidemeyer, F. A. Medina, and W. Kiessling (2012), Integrated bio- and lithofacies analysis of coarse-grained, tide-dominated deltaic environments across the Cretaceous/Paleogene boundary in Patagonia, Argentina, Cretac. Res., 36, 37-57, doi:10.1016/j.cretres.2012.02.002

Schiøler, P., H. Brinkhuis, L. Roncaglia, and G. J. Wilson (1997), Dinoflagellate biostratigraphy and sequence stratigraphy of the type Maastrichtian (Upper Cretaceous), ENCl quarry, The Netherlands, Mar. Micropaleontol., 31(1-2), 65-95, doi:10.1016/S0377-8398(96)00058-8.

Schmidt, A., et al. (2016), Selective environmental stress from sulphur emitted by continental flood basalt eruptions, Nat. Geosci., 9, 77-82, doi:10.1038/ngeo2588.

Schoene, B., K. M. Samperton, M. P. Eddy, G. Keller, T. Adatte, S. A. Bowring, S. F. R. Khadri, and B. Gertsch (2015), U-Pb geochronology of the Deccan Traps and relation to the end-Cretaceous mass extinction, Science, 347(6218), 9-12.

Schouten, S., E. C. Hopmans, E. Schefuß, and J. S. Sinninghe Damsté (2002), Distributional variations in marine crenarchaeotal membrane lipids: A new tool for reconstructing ancient sea water temperatures?, Earth Planet. Sci. Lett., 204, 265-274.

Schouten, S., E. C. Hopmans, and J. S. Sinninghe Damsté (2013), The organic geochemistry of glycerol dialkyl glycerol tetraether lipids: A review, Org. Geochem., 54, 19-61.

Schulte, P., R. Speijer, H. Mai, and A. Kontny (2006), The Cretaceous-Paleogene (K-P) boundary at Brazos, Texas: Sequence stratigraphy, depositional events and the Chicxulub impact, Sediment. Geol., 184(1-2), 77-109, doi:10.1016/j.sedgeo.2005.09.021.

Schulte, P., et al. (2010), The Chicxulub asteroid impact and mass extinction at the Cretaceous-Paleogene boundary, Science, 327(5970), 1214-1218, doi:10.1126/science.1177265.

Scotese, C. R., and C. Dreher (2012), GlobalGeology. [Available at http:/www.GlobalGeology.com.]

Shackleton, N. J., and J. P. Kennett (1975), Paleotemperature history of the Cenozoic and the initiation of Antarctic glaciation: Oxygen and carbon isotope analyses in DSDP Sites 277, 279, and 281, Initial Reports Deep Sea Drill. Proj., 29, 743-755.

Sluijs, A., and H. Brinkhuis (2009), A dynamic climate and ecosystem state during the Paleocene-Eocene Thermal Maximum: Inferences from dinoflagellate cyst assemblages on the New Jersey Shelf, Biogeosciences, 6(8), 1755-1781.

Sluijs, A., J. Pross, and H. Brinkhuis (2005), From greenhouse to icehouse; organic-walled dinoflagellate cysts as paleoenvironmental indicators in the Paleogene, Earth-Science Rev., 68(3-4), 281-315, doi:10.1016/j.earscirev.2004.06.001.

Speijer, R. P., and G. J. van der Zwaan (1996), Extinction and survivorship of southern Tethyan benthic foraminifera across the Cretaceous/Paleogene boundary, in Biotic Recovery From Mass Extinction Events, Spec. Publ., edited by M. B. Hart, pp. 343-371, Geol. Soc., London.

Thibault, N., and S. Gardin (2010), The calcareous nannofossil response to the end-Cretaceous warm event in the tropical Pacific, Palaeogeogr. Palaeoclimatol. Palaeoecol., 291(3), 239-252, doi:10.1016/j.palaeo.2010.02.036.

Thibault, N., and D. Husson (2016), Climatic fluctuations and sea-surface water circulation patterns at the end of the Cretaceous era: Calcareous nannofossil evidence, Palaeogeogr. Palaeoclimatol. Palaeoecol., 441-1, 152-164, doi:10.1016/j.palaeo.2015.07.049.

Tobin, T. S., P. D. Ward, E. J. Steig, E. B. Olivero, I. A. Hilburn, R. N. Mitchell, M. R. Diamond, T. D. Raub, and J. L. Kirschvink (2012), Extinction patterns, $\delta{ }^{18} \mathrm{O}$ trends, and magnetostratigraphy from a southern high-latitude Cretaceous-Paleogene section: Links with Deccan volcanism, Palaeogeogr. Palaeoclimatol. Palaeoecol., 350-352, 180-188, doi:10.1016/j.palaeo.2012.06.029.

Torsvik, T. H., et al. (2012), Phanerozoic polar wander, palaeogeography and dynamics, Earth-Science Rev., 114, $325-368$.

Tunik, M., A. Folguera, M. Naipauer, M. Pimentel, and V. A. Ramos (2010), Early uplift and orogenic deformation in the Neuquén Basin: Constraints on the Andean uplift from U-Pb and Hf isotopic data of detrital zircons, Tectonophysics, 489(1), 258-273, doi:10.1016/ j.tecto.2010.04.017.

van Hinsbergen, D. J. J., L. V. de Groot, S. J. van Schaik, W. Spakman, P. K. Bijl, A. Sluijs, C. G. Langereis, and H. Brinkhuis (2015), A paleolatitude calculator for paleoclimate studies, PLoS One, 10(6), e0126946, doi:10.1371/journal.pone.0126946.

Vandenberghe, N., F. J. Hilgen, and R. P. Speijer (2012), The Paleogene period, in The Geologic Time Scale 2012, edited by F. M. Gradstein et al., pp. 855-921, Elsevier, Boston.

Vellekoop, J., A. Sluijs, J. Smit, S. Schouten, J. W. H. Weijers, J. S. Sinninghe Damsté, and H. Brinkhuis (2014), Rapid short-term cooling following the Chicxulub impact at the Cretaceous-Paleogene boundary, Proc. Natl. Acad. Sci. U. S. A., 111(21), 7537-7541, doi:10.1073/ pnas.1319253111.

Vellekoop, J., J. Smit, B. van de Schootbrugge, J. W. H. Weijers, S. Galeotti, J. S. Sinninghe Damsté, and H. Brinkhuis (2015), Palynological evidence for prolonged cooling along the Tunisian continental shelf following the K-Pg boundary impact, Palaeogeogr. Palaeoclimatol. Palaeoecol., 426, 216-228, doi:10.1016/j.palaeo.2015.03.021.

Vellekoop, J., S. Esmeray-Senlet, K. G. Miller, J. V. Browning, A. Sluijs, B. van de Schootbrugge, J. S. Sinninghe Damsté, and H. Brinkhuis (2016), Evidence for Cretaceous-Paleogene boundary bolide "impact winter" conditions from New Jersey, USA, Geology, 44(8), 619-622, doi:10.1130/G37961.1.

Vera, C., G. Silvestri, B. Liebmann, and P. González (2006), Climate change scenarios for seasonal precipitation in South America from IPCC-AR4 models, Geophys. Res. Lett., 33, L13707, doi:10.1029/2006GL025759.

Villalba, R., H. R. Grau, J. A. Boninsegna, G. C. Jacoby, and A. Ripalta (1998), Tree-ring evidence for long-term precipitation changes in subtropical South America, Int. J. Climatol., 18(13), 1463-1478.

Weijers, J. W. H., S. Schouten, O. C. Spaargaren, and J. S. Sinninghe Damsté (2006), Occurrence and distribution of tetraether membrane lipids in soils: Implications for the use of the TEX86 proxy and the BIT index, Org. Geochem., 37, 1680-1693.

Westerhold, T., U. Röhl, I. Raffi, E. Fornaciari, S. Monechi, V. Reale, J. Bowles, and H. F. Evans (2008), Astronomical calibration of the Paleocene time, Palaeogeogr. Palaeoclimatol. Palaeoecol., 257, 377-403, doi:10.1016/j.palaeo.2007.09.016.

Wilf, P., K. R. Johnson, and B. T. Huber (2003), Correlated terrestrial and marine evidence for global climate changes before mass extinction at the Cretaceous-Paleogene boundary, Proc. Natl. Acad. Sci. U. S. A., 100(2), 599-604, doi:10.1073/pnas.0234701100.

Williams, G. L., H. Brinkhuis, M. A. Pearce, R. A. Fensome, and J. W. Weegink (2004), Southern Ocean and global dinoflagellate cyst events compared: Index events for the Late Cretaceous Neogene, in Proceedings of the Ocean Drilling Program. Scientific Results, vol. 189, edited by N. F. Exon, J. P. Kennett, and M. J. Malone, pp. 1-98, Ocean Drill. Program, College Station, Tex.

Witts, J. D., R. J. Whittle, P. B. Wignall, J. A. Crame, J. E. Francis, R. J. Newton, and V. C. Bowman (2016), Macrofossil evidence for a rapid and severe Cretaceous-Paleogene mass extinction in Antarctica, Nat. Commun., 7.

Woelders, L., and R. P. Speijer (2015), Stable seafloor conditions, sea level and food supply during the latest Maastrichtian at Brazos River, Texas, Mar. Micropaleontol., 121, 41-51, doi:10.1016/j.marmicro.2015.10.002.

Zachos, J. C., D. Kroon, and P. Blum (2004) Proceedings of the Ocean Drilling Program, Initial Rep., 208, Ocean Drill. Program, College Station, Tex., doi:10.2973/odp.proc.ir.208.2004. 